\title{
Invasiveness, ecological impacts and control of acacias in southwestern Europe - a review
}

\author{
Cristina Vieites-Blanco and Serafín J. González-Prieto \\ Instituto de Investigaciones Agrobiológicas de Galicia, IIAG-CSIC, Apartado 122, \\ 15780 Santiago de Compostela, Spain \\ Correspondence: Cristina Vieites-Blanco (cristina.vieites.blanco@gmail.com)
}

Received: 22 January 2020 - Revised: 10 May 2020 - Accepted: 28 May 2020 - Published: 9 July 2020

\begin{abstract}
The most prolific acacias in southern Europe (Acacia dealbata, A. melanoxylon and A. longifolia) are rapidly spreading in its westernmost area: Portugal and NW Spain, where congeners with invasion potential are already established. We performed a bibliographic search of acacia invasions in southern Europe and used spatial data on acacia distribution and abiotic parameters in Iberia to check the influence of abiotic factors on acacia invasion. According to our results, in Iberia A. dealbata and A. melanoxylon seem limited by high soil $\mathrm{pH}\left(\mathrm{pH}_{\mathrm{CaCl}_{2}}>5.5\right)$, frequent frosts ( $>21$ to $\left.40 \mathrm{~d} \mathrm{yr}^{-1}\right)$ and low annual precipitation ( $<500$ to $1000 \mathrm{~mm}$ ); data were inconclusive for A. longifolia, while A. saligna prefers neutral soils in the driest and warmest areas. The percentage of area occupied by $A$. dealbata and A. melanoxylon increases significantly with the percentage of burnt surface. In the literature, acacias' invasiveness is usually attributed to their high resprouting and seeding capacity and to native exclusion through their allelopathic potential; symbiotic promiscuity with rhizobia; high environmental plasticity; and adaptation to burnt, cleared and resource-poor land. However, it is unknown how acacias became so invasive in western Iberia, where native Fabaceae shrubs with similar ecological traits (and invaders outside their natural range) are abundant. Invasive acacias can modify fire and water regimes, aboveground biodiversity, and topsoil characteristics (microbial communities, $\mathrm{pH}$, organic matter and macronutrients levels); nevertheless, sound comparisons with mature stands of Iberian legumes for these and other soil properties ( $\mathrm{N}$ fluxes, micronutrients) are lacking. As several acacias outcompete Iberian Fabaceae shrubs partly thanks to enemy release, the introduction of biocontrol agents (as for A. longifolia in Portugal) can be useful for invasion control.
\end{abstract}

\section{Introduction}

Acacia species belong to the subfamily Mimosoideae and family Fabaceae and include roughly 1300 species (Maslin, 2001). Around 1012 of these species are native to Australia and belong to the subgenus Phyllodineae (Richardson and Rejmánek, 2011), presenting traits that make them more invasive than their African relatives (Low, 2012). A third of the Australian acacias are exotic (i.e. present outside their native distribution; Richardson et al., 2011), and 24 of these species are invasive (Richardson et al., 2015). Acacia species outside their natural range whose introduction and posterior spread implies an environmental impact can be considered invasive (European Parliament and Council, 2014). Casual and naturalized Acacia species (i.e. able to establish new self- perpetuating populations; Richardson et al., 2000) are phylogenetically distant (Yessoufou et al., 2016), and the invasive species form small clusters in the phylogeny (Miller et al., 2011). The Acacia genus is one of the most invasive tree genera (Richardson and Rejmánek, 2011), particularly in disturbed environments (Fuentes-Ramírez et al., 2011; Morris et al., 2011; Hernández et al., 2014) and Mediterranean climates (Carvalho et al., 2010; Morris et al., 2011; Lazzaro et al., 2014), which are usually linked to a scarcity of water and nutrients (Morris et al., 2011).

Acacia species have industrial (tannin and pulp production), agroforestry and ornamental uses (Griffin et al., 2011). They were introduced for economic purposes or for rehabilitation of degraded land, but subsequent invasion has resulted in significant economic and environmental impacts (as cal- 
culated in De Wit et al., 2001) that outweigh the economic benefits (Low, 2012; Duponnois et al., 2013; Richardson et al., 2015). However, their use is expected to increase, which could entail a further expansion in their distribution (Griffin et al., 2011). This highlights the importance of carrying out a risk assessment before introducing new species (Low, 2012; Richardson et al., 2015).

In Europe, Acacia species tend to colonize sensitive habitats such as dunes, riverbanks and natural reserves (Lorenzo et al., 2010a). Moreover, invasion of protected areas by Acacia spp. is predicted to increase according to some species distribution models, facilitated by a higher connectivity of protected areas (Vicente et al., 2013). In southern European countries, up to 14 Acacia species, 8 of them with invasive potential, have been introduced (Lorenzo et al., 2010a). The most prolific at present are A. dealbata Link, A. melanoxylon $\mathrm{R}$. Br. and A. longifolia (Andrews) Willd (Lorenzo et al., 2010a), although other congeners are potential invaders (Table 1).

With 13 introduced species (Table 1), half of which are potential invaders and 4 of which are already invading wide zones including most of the natural and national parks (Tables 2 and 3), western Iberia (Portugal, NW Spain) is by far the European region most widely invaded by Acacia species although the mechanisms underlying the invasion process are not fully understood (e.g. how they are able to outcompete Iberian Fabaceae shrubs). Therefore, the purpose of this article is to review the available information on Acacia species invasions which can help (a) to explain why these exotic plants are so successful in western Iberia; (b) to determine the current state of knowledge and to identify knowledge gaps about their effects on the invaded ecosystems; and (c) to discuss the proposed methods for Acacia spp. control and subsequent restoration of the invaded areas, in terms of efficiency and limitations.

\section{Methods}

An exhaustive bibliographic search was carried out with Scopus, Web of Science and Google Scholar to find scientific and technical articles as well as governmental documents on Acacia species invasions in southern Europe, with a special focus on western Iberia. For this purpose, the following keywords were combined with Boolean operators (AND, OR) in the searches: acacia*, biodiversity, climate, control, Croatia, dispersal, distribution, effect*, enemy, eradication, Europe, *fire*, France, Greece, Iberia, impact*, invas*, Italy, Portugal, soil*, Spain and water. These keywords included the most invaded countries in Europe by acacias, as well as abiotic and biotic factors that could potentially affect acacia invasiveness or be affected by the invasion and control methods.

To determine the influence of some abiotic factors on Acacia spp. invasion, we focused on the Iberian Peninsula, lo- cated in SW Europe (Fig. 1). It comprises continental Portugal and Spain with an extent of almost $600000 \mathrm{~km}^{2}$ and large high- or medium-elevation areas in the centre and the north (Loidi, 2017). The peninsula includes two macrobioclimates - Mediterranean, in almost $80 \%$ of the area, and Temperate, mostly in the north (Rivas-Martínez et al., 2017). Its flora comprises more than 6000 species, around $20 \%$ of them endemic and $12 \%$ exotic (Aedo et al., 2017).

The distributions of the most widespread species in Spain (UTM $10 \mathrm{~km} \times 10 \mathrm{~km}$ grid from Sanz-Elorza et al., 2004) and Portugal (presence of Acacia genus in a $10 \mathrm{~km} \times 10 \mathrm{~km}$ grid; Fernandes et al., 2013) were compared with the most detailed data available on soil $\mathrm{pH}\left(\mathrm{CaCl}_{2} ; 5 \mathrm{~km}\right.$ resolution; a geostatistical framework based on regression-kriging was used; European Commission, 2010), fire incidence $(25 \mathrm{~km} \times 25 \mathrm{~km}$ resolution; data from the European Forest Fire Information System; Borrelli et al., 2016), and frost risk and annual precipitation (data collected from 1971 to 2000; AEMET-IMP, 2011). These two maps of acacia presence used for the spatial analysis were chosen on the grounds that they were the ones available with the same resolution $(10 \mathrm{~km} \times 10 \mathrm{~km}$ grid $)$ and covered the entire continental area of Spain and Portugal. However, as the acacia map for Portugal did not differentiate between Acacia species, and to help interpretations of results, we overlapped the Portugal map with a second acacia layer for Portugal (Invasive Plants in Portugal, 2019; Fig. 1) that differentiated the species, although with a lower resolution (province level).

All the aforementioned data were georeferenced and converted to polygons with ArcGIS 9.2. Each colour of the abiotic layers that were georeferenced was attributed to the corresponding value in the original map in the attribute table. These numeric data from abiotic variables were discretized in equal-width intervals. Then, using the "Intersect" function, the overlapping areas (in square kilometres) between each Acacia species presence and the different levels of each abiotic factor were calculated. For each Acacia species, its presence frequency (percentage of occupied area) for each interval of an abiotic factor was calculated as

$f=\frac{A_{\mathrm{i}}}{A_{\mathrm{sp}}}$,

where $A_{\mathrm{i}}$ is the area of the intersect and $A_{\mathrm{sp}}$ is the total area of the species. The significance of the differences between presence frequencies was tested with the arcsine test of equality of percentages (Sokal and Rohlf, 1979).

Results for the Iberian Peninsula were presented without differentiated acacia species (Acacia spp.), while results for the different species were based only on the Spanish data (due to the limitations in Portugal acacia data specified before). 
Table 1. Origin and status of the Acacia species registered in Europe in the wild as invasive (I), established or naturalized (E; as in Richardson et al., 2000), non-established (NE), or unknown (U).

\begin{tabular}{|c|c|c|c|}
\hline Species & Origin & Status & European country (island) \\
\hline A. baileyana F. Muell. & Australia $^{1}$ & $\begin{array}{l}\mathrm{E} \\
\mathrm{NE}\end{array}$ & $\begin{array}{l}\text { Spain }^{4}, \text { France }(\text { Corsica })^{4}, \text { Portugal }(\text { Madeira })^{4} \\
\text { Portugal }^{4}, \text { France } \\
4,5\end{array}$ \\
\hline A. cultriformis A. Cunn. ex G. Don & Australia $^{2}$ & $\mathrm{NE}$ & Portugal $^{4}$, France $^{5}$ \\
\hline A. cyclops A. Cunn. ex G. Don fil. & Australia $^{1}$ & $\begin{array}{l}\mathrm{E} \\
\mathrm{NE}\end{array}$ & $\begin{array}{l}\text { Portugal }^{4}, \text { Spain }^{4} \\
\text { Portugal }(\text { Madeira })^{4}, \text { France }^{5}\end{array}$ \\
\hline A. dealbata Link & Australia $^{1}$ & $\begin{array}{l}\text { I } \\
\mathrm{E} \\
\mathrm{NE}\end{array}$ & $\begin{array}{l}\text { Portugal }^{6}, \text { Spain }^{7}, \text { France }^{5} \\
\left.\text { Portugal (Azores, Madeira) })^{4} \text {, Italy (continental, Sardinia }\right)^{4} \\
\text { Spain }(\text { Balearic Islands) })^{4} \text {, France }(\text { Corsica })^{4}\end{array}$ \\
\hline A. farnesiana $\mathrm{L}$. Willd. & Neotropical $^{1}$ & $\begin{array}{l}\mathrm{E} \\
\mathrm{NE} \\
\mathrm{U}\end{array}$ & $\begin{array}{l}\text { Portugal (Azores, Madeira })^{4} \text {, France }^{4}, \text { Cyprus }^{4} \\
\text { Spain } \\
\text {, Italy }(\text { Sardinia })^{4}, \text { Greece }^{4} \\
\text { France }(\text { Corsica })^{4}\end{array}$ \\
\hline A. longifolia (Andrews) Willd. & Australia $^{1}$ & $\begin{array}{l}\text { I } \\
\text { E } \\
\mathrm{NE} \\
\mathrm{U}\end{array}$ & $\begin{array}{l}\text { Portugal }{ }^{6} \\
\text { Portugal }(\text { Azores, Madeira })^{4}, \text { Spain }^{4}, \text { Italy }^{4} \\
\text { Spain }(\text { Balearic Islands })^{4}, \text { France }^{5},{\text { Italy }(\text { Sardinia })^{4}}^{4} \\
\text { France }(\text { Corsica })^{4}\end{array}$ \\
\hline A. mearnsii De Wild. & Australia $^{1}$ & $\begin{array}{l}\mathrm{I} \\
\mathrm{E}\end{array}$ & $\begin{array}{l}\text { Portugal }^{6}, \text { France }^{5}, \text { Italy }^{5} \\
\text { Spain }^{4}\end{array}$ \\
\hline A. melanoxylon $\mathrm{R}$. Br. & Australia $^{1}$ & $\begin{array}{l}\text { I } \\
\text { E } \\
\text { NE }\end{array}$ & $\begin{array}{l}\text { Portugal }^{6} \\
\text { Portugal }(\text { Azores, } \text { Madeira })^{4}, \text { Spain }^{4}, \text { France }^{4,5}, \mathrm{UK}^{4} \\
\text { Italy (Sardinia }, \text { Sicily) })^{4}\end{array}$ \\
\hline A. pycnantha Benth. & Australia $^{1}$ & $\begin{array}{l}\text { I } \\
\text { E } \\
\mathrm{NE} \\
\mathrm{U}\end{array}$ & 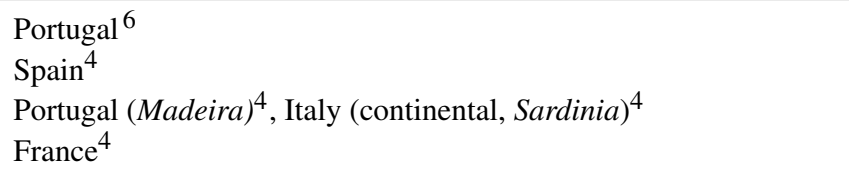 \\
\hline A. salicina Lindley & Australia $^{3}$ & $\mathrm{NE}$ & France $^{5}$ \\
\hline A. saligna Labill. H. L. Wendl. & Australia $^{1}$ & $\begin{array}{l}\text { I } \\
\text { E } \\
\text { NE } \\
\text { U }\end{array}$ & $\begin{array}{l}\text { Portugal }^{6}, \text { France }^{5} \\
\left.\text { Portugal (Azores })^{4} \text {, Spain (continental, Balearic Islands }\right)^{4} \text {, Italy } \\
{\text { (continental, Sardinia, Sicily })^{4}, \text { Greece }^{4}, \text { Cyprus }^{4}}^{\text {Malta }}{ }^{4} \\
\text { France }(\text { Corsica })^{4}\end{array}$ \\
\hline A. retinodes Schltdl. & Australia ${ }^{1}$ & $\begin{array}{l}\text { I } \\
\text { E } \\
\mathrm{NE} \\
\mathrm{U}\end{array}$ & $\begin{array}{l}\text { Portugal }^{6} \\
\text { Spain }^{4}, \text { France }^{4,5}, \text { Italy }^{4}, \mathrm{UK}^{5}, \text { Cyprus }^{5} \\
\text { Spain }(\text { Balearic Islands })^{4},{\text { Italy }(\text { Sardinia })^{4}}^{5} \\
\text { Portugal }(\text { Azores })^{5}, \text { France }(\text { Corsica })^{4}\end{array}$ \\
\hline A. verticillata (L'Hér.) Willd. & Australia $^{1}$ & $\begin{array}{l}\mathrm{E} \\
\mathrm{NE}\end{array}$ & $\begin{array}{l}\text { Portugal (continental, Madeira })^{4} \\
\text { Spain }^{4}, \text { France }^{8}\end{array}$ \\
\hline
\end{tabular}

${ }^{1}$ Sheppard et al. (2006). ${ }^{2}$ ANPSA (2012). ${ }^{3}$ MAPAMA (2013). ${ }^{4}$ DAISIE Project (2016; Delivering Alien Species Inventories for Europe). ${ }^{5}$ ISSG (2016). ${ }^{6}$ Ministério do Ambiente (1999). ${ }^{7}$ MAGRAMA (2013). ${ }^{8}$ Muséum National d'Histoire Naturelle (2016). 

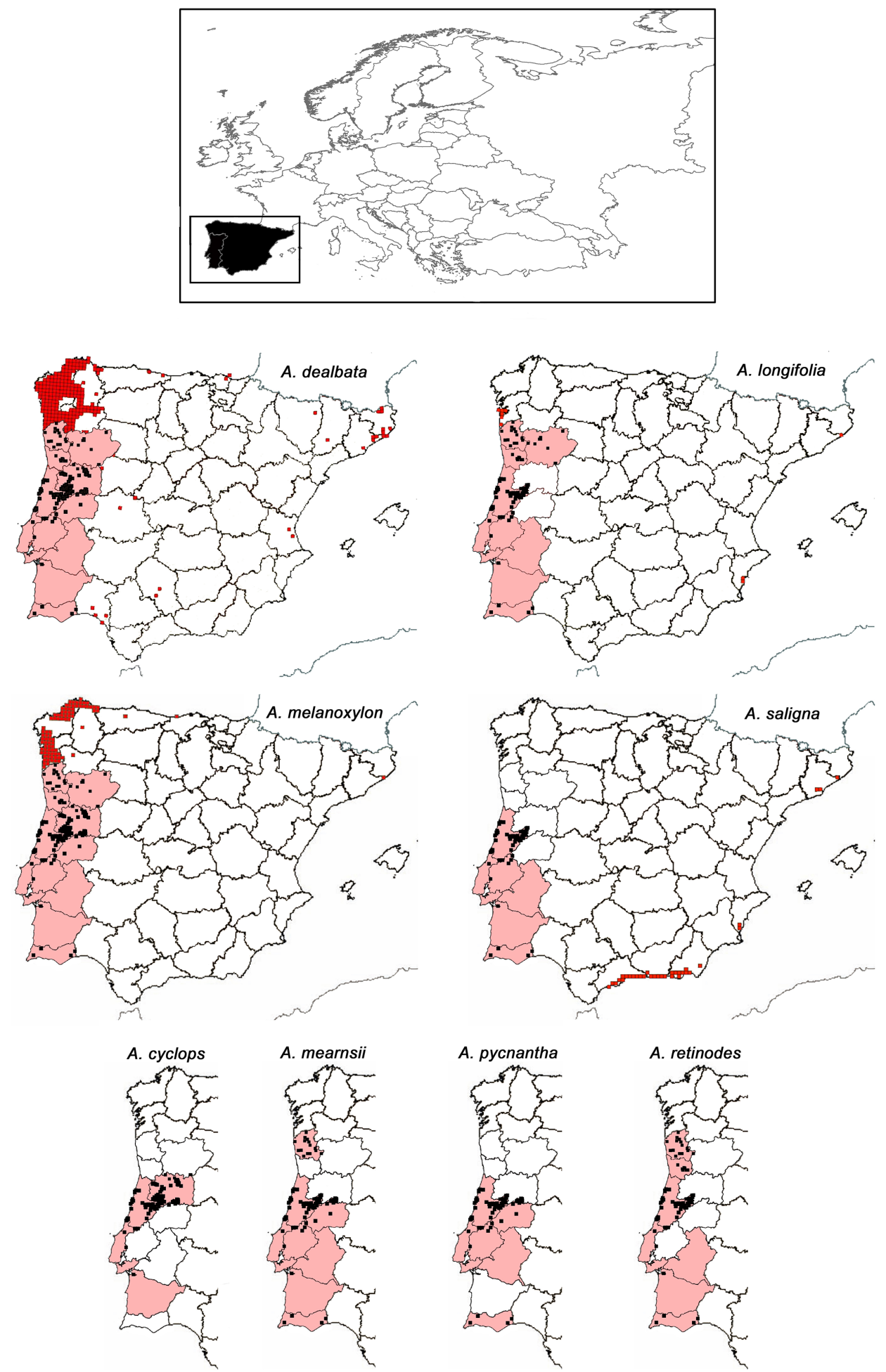

Figure 1. Distribution of invasive Australian Acacia species in the Iberian Peninsula. Data of the distribution of each Acacia species in Spain $(10 \mathrm{~km} \times 10 \mathrm{~km}$ UTM red squares) are taken from Sanz-Elorza et al. (2004). For Portugal we did not find published such detailed information at a species level; therefore, for a given species its presence-absence data per province (invaded provinces in pink; adapted from Invasive Plants in Portugal, 2019) are combined with data of Acacia genus presence on a more detailed scale $(10 \mathrm{~km} \times 10 \mathrm{~km}$ black squares; adapted from Fernandes et al., 2013). At the top of the figure is a map of Europe with the Iberian Peninsula (continental Portugal and Spain) highlighted in black. 
Table 2. Invasive Australian acacias in western Iberia: date and purpose of the introduction, habitats preferentially invaded, and current situation.

\begin{tabular}{|c|c|c|c|c|}
\hline & A. dealbata & A. melanoxylon & A. longifolia & A. saligna \\
\hline Introduction in Portugal & 19 th century (second half) ${ }^{1}$ & 19th century (first half) ${ }^{5}$ & 19th century (second half) ${ }^{7}$ & - \\
\hline Introduction in NW Spain & 20th century ${ }^{2}$ & 20th century (first half) ${ }^{6}$ & 20th century (second half) ${ }^{6}$ & - \\
\hline Purpose of introduction & $\begin{array}{l}\text { Stabilize railway margins, } \\
\text { guides in vineyards } 2,3\end{array}$ & $\begin{array}{l}\text { Ornamental, dune fixation, } \\
\text { improve Eucalyptus } \\
\text { production } 6\end{array}$ & Ornamental, dune fixation ${ }^{7}$ & $\begin{array}{l}\text { Ornamental, control dune } \\
\text { erosion } 9\end{array}$ \\
\hline $\begin{array}{l}\text { Preferential habitat of } \\
\text { invasion }\end{array}$ & Forest ecosystems $^{2}$ & $\begin{array}{l}\text { Riparian forests, Eucalyp- } \\
\text { tus plantations }{ }^{4}\end{array}$ & Dunes, pine plantations 8 & Coastal warm arid areas 9 \\
\hline Current situation & $\begin{array}{l}\text { Expansion (2500 } \text { ha yr }^{-1} \text { in } \\
\text { NW Spain) }\end{array}$ & $\begin{array}{l}\text { Expansion ( } 3100 \text { ha yr }^{-1} \text { in } \\
\text { NW Spain) }\end{array}$ & & \\
\hline
\end{tabular}

${ }^{1}$ Fernandes (2012). ${ }^{2}$ Vazquez-de-la-Cueva (2014). ${ }^{3}$ Lorenzo et al. (2010a). ${ }^{4}$ Hernández et al. (2014). ${ }^{5}$ Heywood and Ball (1968). ${ }^{6}$ Sanz-Elorza et al. (2004). ${ }^{7}$ Neto (1993).

${ }^{8}$ Fernandes et al. (2015). ${ }^{9}$ Marchante et al. (2014).

Table 3. Protected areas in western Iberia invaded by Australian Acacia species. Key: N, naturalized; P, present; I, increasing; CU, control unsuccessfully attempted; NB, nearby populations.

\begin{tabular}{|c|c|c|c|c|c|}
\hline Protected area & A. dealbata & A. melanoxylon & A. longifolia & A. saligna & Acacia sp. \\
\hline Atlantic Islands of Galicia National Park ${ }^{1-3}$ & - & $\mathrm{P}, \mathrm{N}$ & $\mathrm{P}, \mathrm{N}$ & - & - \\
\hline Picos de Europa National Park ${ }^{4}$ & - & $\mathrm{P}, \mathrm{CU}$ & - & - & - \\
\hline Peneda-Gerês National Park ${ }^{5-8}$ & $\mathrm{P}, \mathrm{I}, \mathrm{CU}$ & $\mathrm{P}, \mathrm{I}, \mathrm{CU}$ & - & - & - \\
\hline Baixa Limia - Serra do Xurés Natural Park (personal observation) & $\mathrm{P}, \mathrm{I}$ & $\mathrm{P}, \mathrm{I}$ & - & - & - \\
\hline Fragas do Eume Natural Park ${ }^{9-10}$ & NB & $\mathrm{P}$ & - & - & - \\
\hline Monte Aloia Natural Park ${ }^{11}$ & $\mathrm{P}, \mathrm{I}$ & $\mathrm{P}, \mathrm{I}$ & - & - & - \\
\hline Alvão Natural Park ${ }^{12}$ & $\mathrm{P}$ & - & - & - & - \\
\hline Montesinho Natural Park ${ }^{13}$ & $\mathrm{P}$ & $\mathrm{P}$ & - & - & - \\
\hline Northern Littoral Natural Park ${ }^{14}$ & - & - & $\mathrm{P}$ & - & - \\
\hline Southwest Alentejo and Vicentine Coast Natural Park ${ }^{14}$ & $\mathrm{P}$ & - & - & $\mathrm{P}$ & - \\
\hline Sintra-Cascais Natural Park ${ }^{14}$ & - & - & - & - & $\mathrm{P}$ \\
\hline
\end{tabular}

${ }^{1}$ Bañares et al. (2004). ${ }^{2}$ GEIB (2006). ${ }^{3}$ Fernández-Bouzas et al. (2005). ${ }^{4}$ TRAGSA (2009). ${ }^{5}$ Fernandes-Fontes and Bento-Gonçalves (2005). ${ }^{6}$ Viana and Aranha (2008).

${ }^{7}$ ICNB (2011). ${ }^{8}$ Fernandes et al. (2013). ${ }^{9}$ Pulgar-Sañudo et al. (2006). ${ }^{10}$ Xunta de Galicia (2014). ${ }^{11}$ Lorenzo-Fernández et al. (2000). ${ }^{12}$ Coelho and Alves (2004).

${ }^{13}$ Gonçalves-Aguiar (2000). ${ }^{14}$ ICNF (2016).

\section{Invasiveness of Acacia species in western Iberia}

\subsection{Abiotic factors influencing establishment-spread success}

\subsubsection{Results of the spatial analysis}

All four abiotic factors considered in the spatial analysis (burnt area, soil $\mathrm{pH}$, frost days per year, precipitation) affected acacia presence in the Iberian Peninsula (Table 4). Our results showed that the percentage of occupied area of $A$. dealbata and A. melanoxylon, but not that of A. saligna and A. longifolia, increases significantly with the percentage of burnt surface in the $25 \mathrm{~km} \times 25 \mathrm{~km}$ grids, especially in those over the threshold of $4 \%$ of burnt surface (Table 4, Figs. 1 and 2). Both A. dealbata and A. melanoxylon are by far more frequent in soils with $\mathrm{pH}_{\mathrm{CaCl}_{2}}<5.5$, while A. saligna seems to prefer soils with $\mathrm{pH}_{\mathrm{CaCl}_{2}}=5.5-7.0$, and no conclusive data were obtained for A. longifolia (Table 4, Figs. 1 and 2).
The percentage of occupied area of Acacia species decreases progressively with the number of frost days per year, but the sensitivity to frost was the lowest in A. dealbata, intermediate in A. melanoxylon and the highest in A. saligna; again, the available data were not conclusive for A. longifolia (Table 4). Whereas the highest percentage of occupied area of A. saligna was found in the driest areas (precipitation $<500 \mathrm{~mm} \mathrm{yr}^{-1}$ ), A. dealbata and A. melanoxylon were much more frequent in the rainiest areas (precipitation $>1000 \mathrm{~mm} \mathrm{yr}^{-1}$; Table 4, Figs. 1 and 2), although these results must be interpreted with care due to the low resolution of the precipitation layer.

\subsubsection{Soil characteristics}

In both France and Croatia, acacia spread is limited by high soil pH (Kull et al., 2011; Giovanetti et al., 2014), as we found in our results in the Iberian Peninsula, especially for 
Table 4. Acacia presence frequency (percentage of occupied area) depending on site characteristics. For each species and site characteristic, different letters show significant differences $(\mathrm{a}>\mathrm{b}>\mathrm{c}, p<0.05$; test for equality of percentages of Sokal and Rohlf, 1979).

\begin{tabular}{|c|c|c|c|c|c|}
\hline & Acacia spp. ${ }^{1}$ & A. dealbata ${ }^{2}$ & A. melanoxylon ${ }^{2}$ & A. saligna ${ }^{2}$ & A. longifolia ${ }^{2}$ \\
\hline \multicolumn{6}{|l|}{ Burnt area $^{3}$} \\
\hline$<1.6 \%$ & $4.24^{\mathrm{c}}$ & $2.87^{\mathrm{c}}$ & $1.16^{\mathrm{b}}$ & $0.75^{\mathrm{a}}$ & $0.00^{\mathrm{a}}$ \\
\hline $1.6 \%-4 \%$ & $5.07^{\mathrm{bc}}$ & $3.81^{\mathrm{bc}}$ & $0.04^{\mathrm{b}}$ & $0.45^{\mathrm{a}}$ & $0.05^{\mathrm{a}}$ \\
\hline $4 \%-12 \%$ & $10.15^{\mathrm{ab}}$ & $10.24^{\mathrm{ab}}$ & $2.84^{\mathrm{ab}}$ & $0.65^{\mathrm{a}}$ & $1.36^{\mathrm{a}}$ \\
\hline$>12 \%$ & $16.00^{\mathrm{a}}$ & $20.20^{\mathrm{a}}$ & $11.57^{\mathrm{a}}$ & $0.00^{\mathrm{a}}$ & $0.00^{\mathrm{a}}$ \\
\hline \multicolumn{6}{|l|}{$\mathrm{pH}\left(\mathrm{CaCl}_{2}\right)^{4}$} \\
\hline$<5.5$ & $12.02^{\mathrm{a}}$ & $11.59^{\mathrm{a}}$ & $4.72^{\mathrm{a}}$ & $0.01^{\mathrm{b}}$ & $0.31^{\mathrm{a}}$ \\
\hline $5.5-7.0$ & $1.44^{\mathrm{b}}$ & $0.63^{b}$ & $0.01^{\mathrm{b}}$ & $1.26^{\mathrm{a}}$ & $0.05^{\mathrm{a}}$ \\
\hline$>7.0$ & $0.91^{\mathrm{b}}$ & $0.16^{\mathrm{b}}$ & $0.00^{\mathrm{b}}$ & $0.76^{\mathrm{ab}}$ & $0.12^{\mathrm{a}}$ \\
\hline \multicolumn{6}{|l|}{ Frosts $^{5}$} \\
\hline$<10 \mathrm{dyr}^{-1}$ & $9.72^{\mathrm{a}}$ & $7.35^{\mathrm{a}}$ & $5.09^{\mathrm{a}}$ & $3.02^{\mathrm{a}}$ & $0.64^{\mathrm{a}}$ \\
\hline $11-20 \mathrm{~d} \mathrm{yr}^{-1}$ & $9.17^{\mathrm{a}}$ & $6.44^{\mathrm{a}}$ & $2.69^{\mathrm{ab}}$ & $0.64^{\mathrm{ab}}$ & $0.17^{\mathrm{a}}$ \\
\hline $21-40 \mathrm{~d} \mathrm{yr}^{-1}$ & $6.23^{\mathrm{a}}$ & $4.82^{\mathrm{a}}$ & $0.74^{b c}$ & $0.08^{\mathrm{b}}$ & $0.06^{\mathrm{a}}$ \\
\hline$>40 \mathrm{~d} \mathrm{yr}^{-1}$ & $1.62^{b}$ & $1.49^{b}$ & $0.10^{\mathrm{c}}$ & $0.08^{b}$ & $0.00^{\mathrm{a}}$ \\
\hline \multicolumn{6}{|l|}{ Precipitation $^{5}$} \\
\hline$<500 \mathrm{~mm} \mathrm{yr}^{-1}$ & $1.04^{\mathrm{c}}$ & $0.05^{\mathrm{c}}$ & $0.00^{\mathrm{b}}$ & $0.91^{\mathrm{a}}$ & $0.07^{\mathrm{a}}$ \\
\hline $500-1000 \mathrm{~mm} \mathrm{yr}^{-1}$ & $3.02^{\mathrm{b}}$ & $1.27^{\mathrm{b}}$ & $0.12^{\mathrm{b}}$ & $0.51^{\mathrm{a}}$ & $0.01^{\mathrm{a}}$ \\
\hline$>1000 \mathrm{~mm} \mathrm{yr}^{-1}$ & $24.87^{\mathrm{a}}$ & $20.41^{\mathrm{a}}$ & $9.16^{\mathrm{a}}$ & $0.00^{\mathrm{a}}$ & $0.74^{\mathrm{a}}$ \\
\hline
\end{tabular}

${ }^{1}$ Data from Portugal (Fernandes et al., 2013) and Spain (Sanz-Elorza et al., 2004; see Fig. 1). ${ }^{2}$ Data from Spain (Sanz-Elorza et al., 2004; see Fig. 1). ${ }^{3}$ Calculated on the basis of data from Borrelli et al. (2016), adapted (see Fig. 2). ${ }^{4}$ Data from the Soil pH in Europe map (European Commission, 2010), adapted (see Fig. 2). ${ }^{5}$ Data from the Iberian climate atlas, 1971-2000 (AEMET-IMP, 2011), adapted (see Fig. 2).

A. dealbata and A. melanoxylon, neither of which are present in soils with neutral pHs. However, care should be taken with our results due to the limited resolution of the available soil $\mathrm{pH}$ layer at the continental scale we used.

\subsubsection{Climate}

As Kull et al. (2011) found for France, in the Iberian Peninsula acacia presence is limited by the number of frost days per year (Table 4, Figs. 1 and 2). Richardson et al. (2011) consider that Acacia distribution can potentially expand to other areas that meet the species' climate requirements. Climate change can modify the phenology of invasive species (Morais and Freitas, 2015) and can also increase their invasive potential (Morris et al., 2011). Schortemeyer et al. (2002) found that when Australian acacias are not limited in water and nutrient resources, an increase in $\mathrm{CO}_{2}$ concentration could enhance the growth of most of the studied species (including $A$. dealbata and A. melanoxylon) and increase $\mathrm{N}_{2}$ fixation (in $A$. melanoxylon among others but not in A. dealbata). However, water deficiency due to the variation in climate parameters could favour native species over Acacia invasive species, as predicted for A. dealbata (González-Muñoz et al., 2014). In NW Iberia, regional cli- mate change models for the second half of the 21 st century predict a temperature increase of $2-3{ }^{\circ} \mathrm{C}$, especially in summer and interior areas, and a decrease in precipitation, especially in spring and summer (Álvarez et al., 2011). Therefore, integrated studies at a regional level on the effects of $\mathrm{CO}_{2}$ increase, changes in temperature (including frost risk) and water availability are needed to provide reliable projections of the effect of climate change in these invasive species. In such projections, the higher variability in environmental conditions derived from global change must also be taken into account (Parepa et al., 2013).

\subsubsection{Disturbances}

Acacias present high phenotypic plasticity to environmental factors (Pohlman et al., 2005; Fuentes-Ramírez et al., 2011; Vazquez-de-la-Cueva, 2014), which has been seen to be especially important in other invasive species in coping with disturbances (Daehler, 2003), although it does not always increase competitiveness in limited-resource or highstress habitats (Davidson et al., 2011). Acacia expansion benefits from disturbances such as vegetation clearance carried out in agricultural areas, at roadsides or in abandoned fields (Sanz-Elorza et al., 2004), as well as in burnt areas, where 

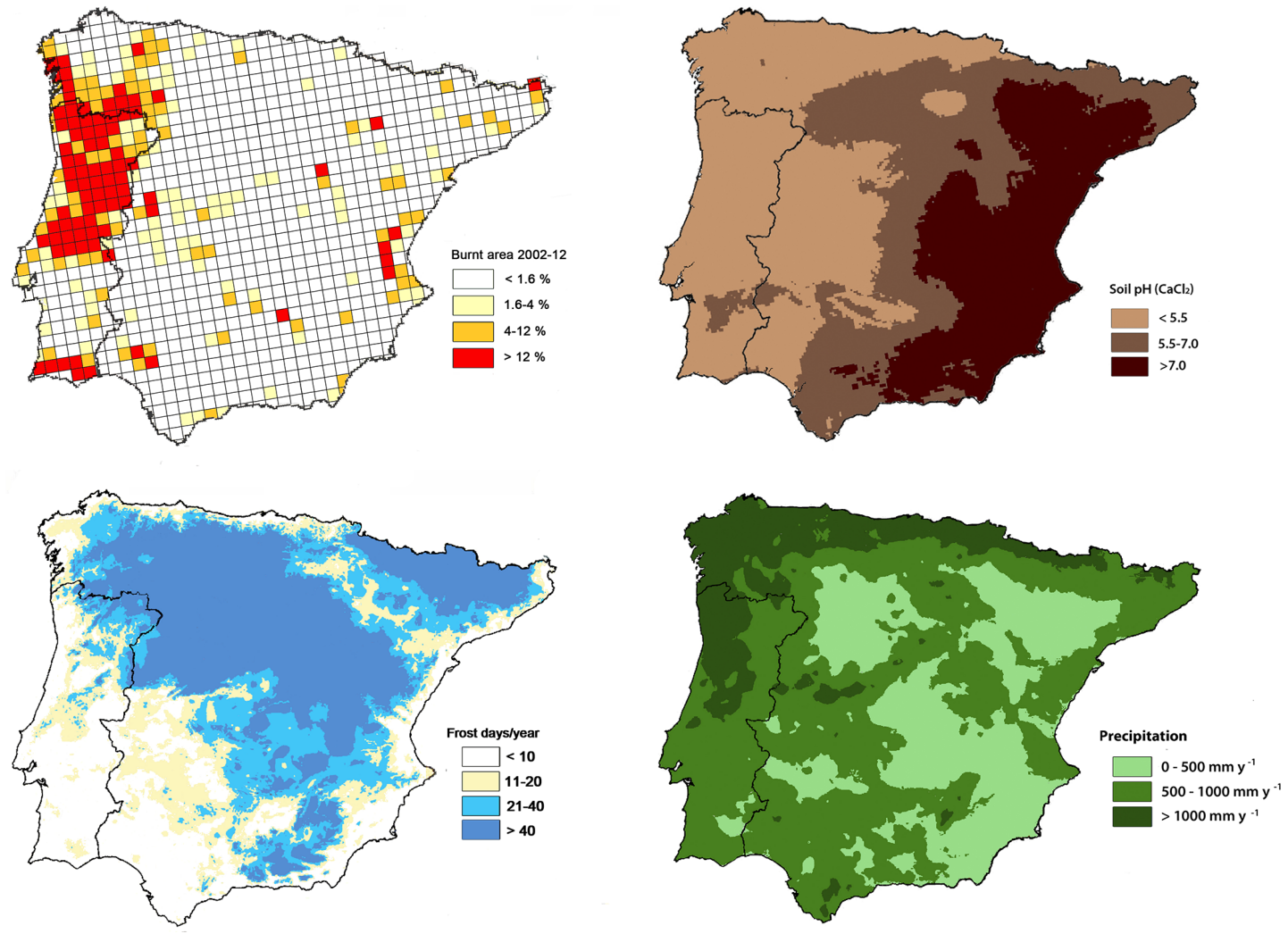

Figure 2. Maps of the Iberian Peninsula for several abiotic characteristics related to Acacia spread: burnt area during the period 2002-2012, adapted from Borrelli et al. (2016); soil pH, adapted from European Commission (2010); frost risk and annual precipitation, both adapted from AEMET-IMP (2011).

a transitory increase in nutrient concentration is coupled to a decrease in nutrient demand due to the absence of vegetation (Keeley et al., 2005). Moreover, the clearing of vegetation can facilitate the establishment of the light-demanding A. dealbata (Sanz-Elorza et al., 2004). Changes in the interactions between plant and soil microorganisms produced by wildfires can increase competitiveness of invasive species over natives, as seen for A. longifolia in a Portuguese dune environment, which could be due to the decrease in soilspecific pathogens (Giovanetti et al., 2014). Wildfires have been related to the expansion of A. dealbata, A. melanoxylon and A. longifolia in southern Europe (Marchante et al., 2003; Lorenzo et al., 2010a; Silva and Marchante, 2012; Hernández et al., 2014; Vazquez-de-la-Cueva, 2014). In western Iberia, where the highest fire incidence in Europe is recorded (Borrelli et al., 2016), Acacia dealbata and A. melanoxylon were found to be favoured by high fire incidence.

The high invasiveness of $A$. dealbata, A. melanoxylon and A. longifolia in burnt areas has been related to their ability to exclude natives through (a) a massive bank of pyrophyte seeds that allow them to regenerate by germination after a disturbance (Richardson and Kluge, 2008; Le Maitre et al., 2011; Wilson et al., 2011), (b) vigorous resprouting (Sheppard et al., 2006) and (c) fast growth rates (as seen in $A$. dealbata, May and Attiwill, 2003). To these advantageous traits, other acacia capacities can be added such as fixing $\mathrm{N}_{2}$ (Lorenzo et al., 2010a; Morris et al., 2011), with high symbiotic promiscuity (Rodríguez-Echeverría et al., 2003), forming dense monospecific stands (Lorenzo et al., 2010b; Werner et al., 2010), and allelopathic potential (Carballeira and Reigosa, 1999; Lorenzo et al., 2010a, 2011; Hussain et al., 2011; Aguilera et al., 2015). All the aforementioned abilities are also present in several native shrubs (Ulex, Pterospartum and Cytisus genera) that have been largely favoured by fires in NW Iberia for at least 6000 years (Kaal et al., 2011). Therefore, it is an unsolved question how A. dealbata, A. melanoxylon and A. longifolia became so invasive in NW Iberian ecosystems, especially taking into account that some Iberian Ulex (Leary et al., 2006; Perry et al., 2014) and Cytisus (Parker, 2000) species are considered dangerous invaders in other countries throughout the world, up to the point of displacing some Acacia species after disturbances such as fire in Australia (Fogarty and Facelli, 1999).

In burnt South African fynbos and other Mediterranean ecosystems, a decline in native legume abundance has been recorded once the post-fire flush of available phosphorus is exhausted, presumably due to a low uptake capacity of the less accessible phosphorus pools (Power et al., 2010). Ac- 
cording to these authors, despite being also legumes, invasive Australian acacias do not show such a decline after fire, possibly because they have broader root and mycorrhizal systems. Nevertheless, in NW Spain native Fabaceae species such as $U$. europaeus can widely dominate post-fire secondary succession for at least 10 years in some areas (Casal, 1987), pointing again to the intriguing ability of some Australian acacias to invade burnt areas in western Iberia.

Despite multiple Acacia adaptations to fire, Vicente et al. (2019) found that climatic factors (for seedlings, saplings and small trees), bedrock and land cover (for medium to large trees) were better predictors of $A$. dealbata invasion in northern Portugal than fire regime.

The high invasiveness of Australian acacias in western Iberia (Portugal and NW Spain; Sanz-Elorza et al., 2004; Fernandes et al., 2013) contrasts with the rest of the Iberian Peninsula and other southern European countries, where they do not present such invasive behaviour or they are more localized (e.g. in acidic soils of Mediterranean France; see Kull et al., 2011). Besides the fact that more species have been introduced there, their invasiveness in western Iberia is partially related to several abiotic factors (Table 4).

\subsection{Biotic factors influencing establishment and spread success}

\subsubsection{Adaptations to low resource availability}

Several traits of acacias can help to explain their success as invasive species in western Iberia and elsewhere. In resource-poor environments, Australian acacias show competitive abilities such as an important allocation of resources to roots (Morris et al., 2011); $\mathrm{N}_{2}$ fixation (Marchante et al., 2003); mycorrhizal associations (Belay et al., 2013); and heteroblasty in some species, such as A. melanoxylon, with phyllodes in the adult stage that increase plant tolerance to drought (Brodribb and Hill, 1993) and nutrient conservation (Morris et al., 2011). Acacia longifolia success in lowresource environments has been associated with high nutrient acquisition rates even under drought conditions (Werner et al., 2010). Although legumes may have difficulties in encountering compatible rhizobia (Parker, 2001), some invasive Acacia species show symbiotic promiscuity (Parker, 2001; Rodríguez-Echeverría, 2010; Rodríguez-Echeverría et al., 2011). For example, in low-nutrient dune soils in Portugal, A. longifolia can be more efficient at associating with rhizobia than native species are; this has been proposed as an important factor in invasion success (Rodríguez-Echeverría et al., 2009). Nevertheless, a high symbiotic promiscuity has also been reported for the $\mathrm{N}_{2}$-fixing Iberian Cytisus, Genista and Retama shrubs (Rodríguez-Echeverría et al., 2003), a trait that would help to explain the invasive ability of Cytisus scoparius (L.) Link in North America, Australia and New Zealand, despite this species being displaced by some Australian acacias in western Iberia.

\subsubsection{Reproductive traits}

Acacias' high colonization capacity is related to their vegetative reproduction (Lorenzo et al., 2010a; Fuentes-Ramírez et al., 2011) and their high investment in flower production, especially for A. dealbata (Correia et al., 2014). Mixed pollination (through honeybees and wind) in A. longifolia has been proposed as a strategy the species uses to succeed in Portugal coastal ecosystems (Giovanetti et al., 2018). Moreover, invasive Acacia species are able to rapidly build a massive and persistent seed bank (Gibson et al., 2011; Le Maitre et al., 2011; Vazquez-de-la-Cueva, 2014) owing to a short generation time, long fruiting period, large seed number, small seed size, and prolonged and high seed viability (Alpert et al., 2000; Table 5). Propagule pressure after disturbances is an important facilitator of invasion for some exotic species (Catford et al., 2012). Nevertheless, it must be highlighted that, despite being displaced by Acacia spp. in western Iberia, several Iberian Fabaceae shrubs, such as Cytisus scoparius and Ulex europaeus L., share all these reproductive traits, which have been considered important factors for their high invasiveness in North America, Australia and New Zealand (Richardson and Hill, 1998; Bossard, 2000; Clements et al., 2001; Hill et al., 2001).

Long-distance endozoochory of seeds by birds has been found in South Africa for A. cyclops (Mokotjomela et al., 2015) and A. melanoxylon (Global Invasive Species Database, 2016) and for the latter species also in Portugal (Heleno et al., 2011). However, zoochory in acacia species is mostly associated with ants (Marchante et al., 2010; Wandrag et al., 2013; Pascov et al., 2015), and, consequently, few A. longifolia seeds have been seen to disperse over long distances in Portugal (Marchante et al., 2010). Dispersion can also be facilitated by habitat properties such as connectivity (Saad et al., 2009; Vicente et al., 2013; see Hernández et al., 2014, for A. dealbata and A. melanoxylon).

\subsubsection{Enemy release}

Invasive species success has been associated in some cases with enemy release, because in the invaded area their specialist enemies are not present, which gives them a competitive advantage over native species (Keane and Crawley, 2002; Lorenzo et al., 2010a). Evidence of enemy release has been found comparing invasive (Portugal) and native (Australia) populations of $A$. dealbata and A. longifolia, as Portuguese populations showed less pre-dispersal predation and higher production of fully developed seeds per fruit and bigger seeds (Correia et al., 2016). Another study comparing native and invaded areas in Australia of several acacia species (including A. longifolia and A. melanoxylon) did not find evidence of enemy release in soil microbial communities, which the authors attributed predominantly to the high homogeneity of vegetation and to the dominance of shrubby leguminous plants throughout Australia (Birnbaum and Leish- 
Table 5. Reproductive traits of the most widespread Acacia species in southern Europe and two abundant native legumes (Ulex europaeus and Cytisus scoparius) in western Iberia.

\begin{tabular}{|c|c|c|c|c|}
\hline & $\begin{array}{r}\text { Age of maturity } \\
\text { (years) }\end{array}$ & $\begin{array}{l}\text { Seed bank } \\
\left(\text { seeds } \mathrm{m}^{-2}\right)\end{array}$ & $\begin{array}{r}\text { Seed viability } \\
(\%)\end{array}$ & $\begin{array}{r}\text { Seed persistence } \\
\text { (years) }\end{array}$ \\
\hline Acacia dealbata & $4-5^{\mathrm{a}}$ & $10000-22500^{\mathrm{c}}$ & $30-90^{c}$ & $>5^{\mathrm{b}}$ \\
\hline Acacia longifolia & $2^{b}$ & $500-34000^{\mathrm{c}}$ & $88-99^{3}$ & $>10^{\mathrm{b}}$ \\
\hline Acacia melanoxylon & $2^{\mathrm{a}}$ & $\sim 50000^{\mathrm{c}}$ & $70-91^{\mathrm{c}}$ & $>50^{\mathrm{a}}$ \\
\hline Ulex europaeus & $3^{\mathrm{d}}$ & $\begin{array}{l}650-1050{\text { (native })^{\mathrm{f}}}^{2500-16000 \text { (invasive }^{\mathrm{g}}}\end{array}$ & $25^{j}$ & $26^{1}$ \\
\hline Cytisus scoparius & $2-5^{\mathrm{e}}$ & $\begin{array}{l}30-10000{\text { (native })^{\mathrm{h}}} \\
30000 \text { (exotic }^{\mathrm{i}}\end{array}$ & $69-98^{\mathrm{k}}$ & $5-30^{\mathrm{m}}$ \\
\hline
\end{tabular}

${ }^{a}$ WorldWideWattle (2016). ${ }^{b}$ Brown and Bettink (2009). ${ }^{c}$ Gibson et al. (2011). ${ }^{\mathrm{d}}$ CABI (2016b). ${ }^{\text {e }}$ Sheppard et al. (2006). ${ }^{\mathrm{f}}$ Puentes et al. (1988). ${ }^{\mathrm{g}}$ Moore et al. (2006). ${ }^{\mathrm{h}}$ Rees and Paynter (1997). ${ }^{\mathrm{i}}$ Downey (2001). ${ }^{\mathrm{j}}$ Ivens (1982). ${ }^{\mathrm{k}}$ CABI (2016a). ${ }^{\mathrm{l}}$ Moss (1959). $\mathrm{m}$ Maryland Department of Agriculture (2015).

man, 2013). On the other hand, the enemy release hypothesis has been used to explain the invasiveness of some western Iberia autochthonous shrubby legumes (Ulex europaeus, Cytisus scoparius) outside their native range (Memmott et al., 2000; Hornoy et al., 2011). The fact that some Australian acacias and Iberian shrub legumes reciprocally outcompete each other outside their native range arises as a supporting argument for the enemy release hypothesis.

\subsubsection{Empty niche}

Native legumes in western Iberia are shrubs, so the fact that A. dealbata and A. melanoxylon are the unique leguminous trees in the invaded areas could partly explain their establishment as they would be filling an empty niche. In the case of A. longifolia, it is considered a shrub or small tree due to its low height. The empty niche hypothesis has been recurrently used to explain invasiveness (Hierro et al., 2005). At an intermediate successional stage, A. dealbata and A. melanoxylon might have, as wooded trees, a competitive advantage over native shrubs. However, it must be highlighted that some native legumes (Ulex europaeus, Cytisus striatus) which are frequent in western Iberia can easily reach up to 2.5-3 m height and that in many areas, due to high fire recurrence, the invasive acacias do not exceed that height.

\subsubsection{Human-mediated factors}

Acacia species dispersal can be enhanced through their economic exploitation (Castro-Díez et al., 2011) and due to the movement of soil as a result of human activities (Hodkinson and Thompson, 1997). In fact, all acacia species widely used in forestry have become invasive (Richardson et al., 2015), likely thanks to the existence of disturbed areas along infrastructures (forest tracks, roads) which can act as dispersal corridors, as well as to involuntary transport and dispersal of seeds during forest management activities. Propagule pressure has also been enhanced in coastal ecosystems through acacia use for dune stabilization (Marchante et al., 2003) or on roads and in human-disturbed areas due to their deliberately introduction as ornamental trees (Fuentes-Ramírez et al., 2010). Propagule pressure has been considered, jointly with residence times, one of the major drivers of acacia invasiveness (Richardson et al., 2015) and in some cases may have been confused with acacia invasiveness traits due to their overlap with traits associated with human usefulness (Richardson et al., 2011). Land abandonment and misuse in rural areas can also favour acacia invasion (Souza-Alonso et al., 2017). Cultural perception of these species can also play in their favour. For example, in Spain and Portugal, Acacia dealbata has been greatly appreciated in rural areas for the last 50 years (Souza-Alonso et al., 2017), and acacias provide different benefits such as timber or honey production (Vaz et al., 2019). Eucalyptus globulus Labill. plantations can favour acacias through facilitative interactions (Forrester et al., 2011, although see also Rodríguez-Echeverria et al., 2013); these mixtures are common in both NW Spain (Hernández et al., 2014) and Portugal (Martins et al., 2016).

\section{Effects of acacias on the invaded soil-plant system}

\subsection{Effects on biodiversity}

Acacia species can lead to a biotic homogenization of ecosystems (Lorenzo et al., 2010a; Lorenzo and RodríguezEcheverría, 2012) and to the decrease in biodiversity of soil bacteria (Slabbert et al., 2014), invertebrates (as found for Coleoptera in A. dealbata by Coetzee et al., 2007) and plants (for A. longifolia see Marchante et al., 2003, 2015; Hellmann et al., 2011; for A. dealbata see Fuentes-Ramírez et al., 2010; González-Muñoz et al., 2012; Lorenzo et al., 2012; Lazzaro et al., 2014).

Acacias are often able to exclude native plants (FuentesRamírez et al., 2011; Le Maitre et al., 2011) through (a) high competition capacity in resource-poor environments (Bro- 
dribb and Hill, 1993; Marchante et al., 2003; Werner et al., 2010; Morris et al., 2011; Belay et al., 2013), (b) a tendency to form monospecific stands (Lorenzo et al., 2010b; Werner et al., 2010; Vazquez-de-la-Cueva, 2014) and (c) the depletion of native seed banks derived from the suppression of native plant species (Marchante et al., 2003; Lorenzo et al., 2010a; Le Maitre et al., 2011).

Other exclusion factors are their allelopathic ability (as found in A. dealbata - Carballeira and Reigosa, 1999; Lorenzo et al., 2010a, 2011; Aguilera et al., 2015 - and in A. melanoxylon - Hussain et al., 2011) and the formation of a thick litter layer (Lorenzo et al., 2010b; Le Maitre et al., 2011; González-Muñoz et al., 2012) which can inhibit the germination and establishment of plants with small seeds (Marchante et al., 2011a). Allelopathy in A. dealbata is related to flowers (Carballeira and Reigosa, 1999; Aguilera et al., 2015), and, in Iberia, its flowering coincides with the germination period of most native species, increasing the allelopathic effects of the invasive species (Lorenzo et al., 2010a). Allelopathy can be presumed to be a novel weapon that increases the competitiveness of A. dealbata (Lorenzo et al., 2011), in accordance with the "novel weapon hypothesis", which states that root exudates of invasive species can be highly damaging to native plants or soil microorganisms because invasive and native species have not coevolved (Callaway and Ridenour, 2004; Weidenhamer and Callaway, 2010). However, some Fabaceae shrubs native to western Iberia, where they are being displaced by some Acacia species, also have allelopathic potential, as reported for Cytisus scoparius (Nemoto et al., 1993), and also share with acacias many of the other aforementioned traits (high competition capacity, monospecific stands, thick litter layer; CABI, 2016a, b).

\subsection{Alteration of ecosystem functioning}

\subsubsection{Fire regime}

In South African fynbos invasive Acacia species provide more fuel load than native species (Van Wilgen and Richardson, 1985); they can alter the fire regime and characteristics, and, consequently, a relation between more frequent fires and diminishing soil nutrient concentration in the long term could be anticipated (Ehrenfeld, 2010). If this is also the case in western Iberia, which already has the highest wildfire incidence in Europe (Borrelli et al., 2016), a worrying scenario with a fire-invasion positive feedback could arise. However, due to the meaningful ecological and environmental differences between both areas, studies on the effect of these invaders on the fire regime of western Iberia are needed. Contrastingly, in fynbos, the higher humidity of A. saligna tissues has resulted in a decrease in fire intensity (Van Wilgen and Richardson, 1985).

\subsubsection{Water regime}

In South African fynbos, Acacia species decrease stream flows through higher water use and evapotranspiration (Le Maitre et al., 2002, 2011; Morris et al., 2011) and even change water quality (Chamier et al., 2012). In this habitat, Acacia species invasions have resulted in increased soil erosion of riverbanks because the Acacia invaders are not adapted to floods (D'Antonio and Meyerson, 2002). In Iberia, some of the most invasive acacias (A. dealbata, A. longifolia) widely colonize the river margins (Marchante et al., 2005; Fagúndez and Beiras, 2007; Lorenzo et al., 2010a), especially those that have been channelized (Aguiar et al., 2001). However, still little is known about their effects on the hydrological cycle, although A. longifolia has been seen to alter the ecosystem water balance in a semi-arid region (Rascher et al., 2011).

\subsubsection{Soil}

Acacia spp. can modify soil properties (Ehrenfeld et al., 2001; Marchante et al., 2008; Lorenzo et al., 2010b; SouzaAlonso et al., 2014), for instance through their recalcitrant phyllodes and $\mathrm{N}_{2}$-fixing capacity (Lorenzo et al., 2010a; Morris et al., 2011; Castro-Díez et al., 2012). Owing to its ability to fix $\mathrm{N}_{2}, A$. dealbata produces a high amount of nutrient-rich litter that decomposes quickly (Witkowski, 1991; Souza-Alonso et al., 2014, 2015a) although the presence of secondary metabolites may cause the opposite effect (Castro-Díez et al., 2012). Consequently, its invasion commonly results in lower $\mathrm{pH}$ (except in very acidic soils) and higher contents of $\mathrm{C}$, total $\mathrm{N}$, inorganic $\mathrm{N}$ and $\mathrm{P}$ in the topsoil (May and Attiwill, 2003; Lorenzo et al., 2010b; GonzálezMuñoz et al., 2012; Lazzaro et al., 2014; Souza-Alonso et al., 2014, 2015a). Similar patterns have also been found for other Acacia species, namely increased soil organic matter and $\mathrm{N}$ content (A. longifolia - Marchante et al., 2008; RodríguezEcheverría et al., 2009; Hellmann et al., 2011; A. saligna Yelenik et al., 2004, 2007). The increase in soil N concentration has been seen to expand beyond the invaded area for $A$. longifolia (Rascher et al., 2012). Soil C, N and P enzymatic activities ( $\beta$-glucosidase, $\mathrm{N}$-acetylglucosaminidase, urease, acid phosphatase) also increased after the invasion (SouzaAlonso et al., 2014, 2015a). Nevertheless, there is still a lack of knowledge about the effects of acacias on the net and gross $\mathrm{N}$ fluxes of the invaded ecosystems. Moreover, in the bibliographic search we could not find sound comparisons of soil $\mathrm{N}$ pools between acacia-invaded sites and mature stands of native Fabaceae, namely Ulex europaeus or Cytisus scoparius.

Soil base cations ( $\mathrm{Na}, \mathrm{K}, \mathrm{Mg}, \mathrm{Ca}$ ) under $A$. dealbata have been less studied and show different responses, variable with time (Souza-Alonso et al., 2014, 2015a), which underlines the importance of the time elapsed after invasion for soil property variations (Strayer et al., 2006; Marchante et al., 
2008; Souza-Alonso et al., 2015a). However, as found in $A$. longifolia (Marchante et al., 2008; Hellmann et al., 2011) and A. saligna (Yelenik et al., 2007), an increase in exchangeable base cation concentration due to the uplift of nutrients to shallower soil layers and to the higher cation exchange capacity derived from the increment in organic matter content would be expected (Dassonville et al., 2008). We found a lack of studies about the effect of invasive acacias on soilavailable micronutrients, despite their importance in plant survival and development when present in limiting or deleterious concentrations (Williams and Fraústo da Silva, 2000). As for soil N, no sound comparisons of soil nutrients between Acacia spp.-invaded sites and mature stands of native Fabaceae species were found.

Acacia dealbata can also affect the structure and function of soil bacterial and fungal communities (Lorenzo et al., 2010b; Rodríguez-Echeverría, 2010; Lorenzo et al., 2013; Souza-Alonso et al., 2015a) that vary with the ecosystems invaded (Lorenzo et al., 2010b). Allelopathy affects soil microorganisms differently depending on the ecosystem (Lorenzo et al., 2013). In the long term, by changing soil properties and microbiota composition, A. dealbata and A. longifolia seem to favour (a) their own invasion, as they benefit from the increased nutrient soil content and compatible $\mathrm{N}_{2}$-fixing bacteria availability (Marchante et al., 2008; Lorenzo and Rodríguez-Echeverría, 2012; RodríguezEcheverría et al., 2013), and (b) the proliferation of nitrophilous species, which can result in secondary invasions (Le Maitre et al., 2011; González-Muñoz et al., 2012; Lazzaro et al., 2014; Marchante et al., 2015).

Consequently, the above-mentioned Acacia invasive species can be considered "ecosystem transformers" (Richardson et al., 2000) as they act at least as donors of limiting nutrients ( $\mathrm{N}$ in low-resource ecosystems) and also as fire promoters, sand stabilizers and litter accumulators.

\section{Acacia species control and subsequent restoration of the soil-plant system}

\subsection{Physical and chemical control}

In the case of Acacia species, a very common control technique is cutting, which should be accompanied by herbicide application in the case of vigorous resprouting species (Le Maitre et al., 2011; Souza-Alonso et al., 2013). The use of the herbicide triclopyr in A. dealbata is effective and not detrimental to soil microorganism activity in the long term according to results obtained in NW Spain (Souza-Alonso et al., 2013), although it has been associated with structural variations in soil bacteria communities during the first year after the herbicide application (Souza-Alonso et al., 2015b). Basal cutting has been employed for A. longifolia control in Portugal, sometimes followed by herbicide use to avoid resprouting; however, a low success rate was obtained due to the high contribution of seed germination to the reinvasion (see Marchante et al., 2011a, and references therein). Also, in many localities the herbicide is only applied several hours or days after cutting, which reduces its success (Ana S. Vaz, personal communication, 30 March 2020). Controlling species (e.g. A. dealbata, A. melanoxylon, A. mearnsii) with trunk debarking of all trees from waist height down to the soil surface, when the vascular cambium is active, is being carried out in Portugal (Silva and Marchante, 2012). There are alternatives to the complete elimination of the invasive plant by using the aforementioned control methods: lowering their density, in order to reduce the cost of a subsequent control, or hindering their spread if the available budget is not enough for applying a control technique (Myers et al., 2000). Moreover, the persistent seed bank of acacias can be decreased with prescribed burning or solarization; the combination of both methods can be highly effective for A. saligna (Cohen et al., 2018).

\subsection{Biological control}

As highlighted previously (see "Enemy release" subsection), the absence of specialized predators or parasites can be a decisive competitive advantage for invasive Acacia species in western Iberia. Therefore, biological control by introducing natural enemies arises as a promising technique for Acacia species control in this region.

In South Africa, seed predator Melanterius beetles have been introduced to control A. baileyana F. Muell., A. dealbata, A. mearnsii and A. pycnantha (M. maculatus Lea); A. saligna (M. compactus Lea); A. longifolia (M. ventralis Lea); A. cyclops (M. servulus Pascoe); and A. melanoxylon (M. acaciae Lea), the introduction being successful for the three latter cases (Sheppard et al., 2006; Wilson et al., 2011). Trichilogaster hymenopterans (bud-galling wasps) have also been successfully employed to control A. longifolia (T. acaciaelongifoliae (Froggatt)) and A. pycnantha ( $T$. signiventris (Girault); Hoffmann et al., 2002; Sheppard et al., 2006). Besides, the flies Dasineura dielsi Rübsaamen and $D$. rubiformis Kolesik have been tested for A. cyclops and A. mearnsii control, respectively (Wilson et al., 2011). Among fungi, the basidiomycete Uromycladium tepperianum (Sacc.) McAlpine, which causes gall rust, extensively damages $A$. saligna (Sheppard et al., 2006; Wilson et al., 2011).

Among the six natural enemies of acacias successfully employed to control acacias invasions in South Africa, only T. acaciaelongifoliae has been released in western Iberia to control A. longifolia after the study of Marchante et al. (2011b) and the approval of the EFSA PLH Panel (2015). This agent can largely reduce seed production, decreasing the capacity of dispersal and reinvasion of A. longifolia (Invasive Plants in Portugal, 2019). Regarding A. dealbata, biological control techniques have not yet been used, despite this species being one of the invasive plants most prioritized as a potential biocontrol target in western Europe (Sheppard et al., 2006). However, the administrative and scientific pro- 
cedures to introduce two potential agents - Melanterius acaciae Lea and Melanterius maculatus Lea - have been initiated in Portugal for the control of A. melanoxylon and A. dealbata, respectively (Carrapeto Gil, 2017).

\subsection{Ecosystem restoration}

After Acacia species removal, in order to recover ecosystem composition and function (Le Maitre et al., 2011; GonzálezMuñoz et al., 2012) and to avoid side effects such as reinvasion or erosion (Enright, 2000; Marchante et al., 2011a), proactive restoration may be needed. Restoration efficiency depends on the understanding of the processes by which invasive acacias alter the environment (Le Maitre et al., 2011). In order to facilitate the recovery of the ecosystem, eradication should be accompanied by the elimination through physical removal or burning of acacia litter (Marchante et al., 2004, 2009; Le Maitre et al., 2011), which affects soil properties and can enhance secondary invasions through increased N (Yelenik et al., 2004; Marchante et al., 2009; Le Maitre et al., 2011). Corbin and D'Antonio (2004) suggest that invasive species not only affect soil $\mathrm{N}$ fluxes but also $\mathrm{N}$ pools, making restoration efforts increasingly difficult. In some cases, removal of the exotic species might not be enough due to the legacy effects produced in the ecosystem (D'Antonio and Meyerson, 2002), for example when $\mathrm{N}_{2}$ fixing species lead to a persistent increase in $\mathrm{N}$ concentration that can hinder restoration efforts (Yelenik et al., 2007). Acacia species leave persistent alterations in soil that can hamper restoration efforts and create a need for complementary actions such as reducing $\mathrm{N}$ availability (as is the case for A. longifolia; Marchante et al., 2009) in naturally N-poor ecosystems. The addition of a C-rich source that leads to $\mathrm{N}$ immobilization can counteract the decreased $\mathrm{C}: \mathrm{N}$ ratio through $\mathrm{N}_{2}$ fixing, thereby avoiding secondary invasions by $\mathrm{N}$-demanding species (Yelenik et al., 2004). However, lowering resource availability would not be an effective strategy with species that invade low-resource environments (Funk and Vitousek, 2007).

Regeneration with native species by active planting or sowing can be considered after the eradication of invasive species (Richardson et al., 2007). This is especially important for species such as A. dealbata and A. longifolia that deplete the native soil seed bank and reduce plant diversity (Marchante et al., 2011a; González-Muñoz et al., 2012). In order to avoid future invasions, Funk et al. (2008) propose revegetating with native species with similar attributes to invaders but ones that do not modify their environment in a similar way, with the objective of filling ecological niches. Although this is not possible when invaders occupy an empty ecological niche, as happens with Australian Acacia spp. that invade low-nutrient coastal dunes in Portugal (RodríguezEcheverría et al., 2009), it can be feasible in forest or shrubland areas which are usually colonized by native legumes (Ulex, Cytisus, Pterospartum). When the invasion has been triggered by changes in disturbance regimes, the control of exotic plant populations and regeneration with natives could be ineffective; thus management should focus on reverting environmental changes (Catford et al., 2012).

\subsection{Constraints on control and restoration}

Several reproductive characteristics of invaders that may restrict their control success, such as large and persistent seed banks (Wilson et al., 2011), vigorous resprouting and high propagule dispersal capacity (Myers et al., 2000; Panetta, 2009), are common traits in Acacia spp. (Lorenzo et al., 2010a; Fuentes-Ramírez et al., 2011; Gibson et al., 2011; Le Maitre et al., 2011; Vazquez-de-la-Cueva, 2014). As a consequence, the management of this genus is difficult and control actions can have strong side effects. For example, using fire to stimulate germination (and by that, deplete the seed bank; Wilson et al., 2011) may affect the native seed bank, favour secondary invasions (Nsikani et al., 2019) and induce Acacia spp. sprouting (Le Maitre et al., 2011), which is one of the main factors that makes the control of these invaders very difficult in post-fire situations (Silva and Marchante, 2012). If litter removal, earth covering or soil inversion are used to avoid germination (Wilson et al., 2011), they can increase erosion risk and expose soil to higher $\mathrm{N}$ mineralization which can hamper native species recolonization (Yelenik et al., 2004), as also occurs after tree removal (D'Antonio and Meyerson, 2002). Moreover, restoration efforts that cause disturbances in the invaded areas can enhance secondary invasions by other species (Le Maitre et al., 2011).

Other examples of side effects on native species include (a) the use of herbicides to prevent resprouting of Acacia species, which could indirectly affect natives through effects on symbiotic microorganisms (Weidenhamer and Callaway, 2010); (b) the use of biological control, which can lead to unexpected impacts on non-target species (Cory and Myers, 2000); and (c) the addition of a $\mathrm{C}$ source to counteract the decline in the litter and soil $\mathrm{C}: \mathrm{N}$ ratio triggered by Acacia spp. invasions, which can affect native species (Haubensak et al., 2004).

Increased time after invasion exacerbates all these constraints, as acacias' seed banks become larger (Marchante et al., 2010), changes in soil properties and microbial communities become more pronounced (Marchante et al., 2008; Souza-Alonso et al., 2015a), and distribution widens (Myers et al., 2000). Consequently, as for other species (Myers et al., 2000; Catford et al., 2012; Monaco and Genovesi, 2014), a preventive approach should prevail over a reactive one in acacia invasion control (Sanz-Elorza et al., 2004; Wilson et al., 2011). For instance, fire prevention and control are strongly recommended to preclude A. dealbata spread in Spain (SanzElorza et al., 2004). However, once the species is introduced, the possibility of restoring the affected area must be considered (Myers et al., 2000), and, due to the high cost of restoration, it is necessary to select areas that are most af- 
fected or where management has the highest probability of success (D'Antonio and Meyerson, 2002). For example, in the case of $A$. longifolia, recently invaded areas should be prioritized (Marchante et al., 2011b).

As management outcomes cannot be accurately predicted, an adaptive approach is needed through continuous monitoring and assessment of the restoration actions (Van Wilgen et al., 2011). Also, regional strategies should be implemented for dealing with invasive acacia species. The coordination of efforts from national to municipal levels, with clear lines of responsibilities, and involvement of the private sector can effectively achieve restoration goals (Van Wilgen et al., 2011).

Another challenge in acacia control and restoration is the delay in the implementation of European laws. EU regulation was implemented in 2015 (European Parliament and Council, 2014), setting guidelines for the management of invasive species and highlighting the need for prevention, early detection, and rapid eradication and management. However, it was not until 2019 that this European regulation was implemented in Portugal (Decree-Law 92/2019) and Spain (Real Decreto 216/2019). The reinforcement of transnational forest regulations for the southern European countries could help to prevent introductions of new acacia species (Souza-Alonso et al., 2017).

\section{Conclusions}

Due to their high invasiveness, Acacia dealbata, A. melanoxylon and A. longifolia are at present the most prolific invader acacias in western Iberia, the European region where acacia invasions are most widespread. This is likely due to the combination of several factors: (a) greater introduction effort, (b) acidic soils, (c) a temperate and humid climate, and (d) the highest wildfire incidence in Europe. Because of the strong changes they induce in the soil-plant system, these species are highly damaging to the environment, which is particularly worrying for the protected areas where they are present. Besides these species, other congeners are widening their distributions in Iberia and can emerge as dangerous future invaders. Therefore, more research is needed on the least known Acacia species to prevent new invasions and to predict which areas are the most vulnerable to their invasion.

Further studies are also needed on how Acacia species became so invasive in ecosystems where native species with similar ecological traits $\left(\mathrm{N}_{2}\right.$ fixing, resprouters, pyrophytes, able to form monospecific stands, allelopathic potential) are already abundant and widespread. Moreover, for European ecosystems there is no available information about the effects of invasive acacias on fuel load and fire risk, despite the fact that acacia expansion in burnt areas is a cause of great concern. This knowledge would enable the use of more efficient preventive, control and restoration practices. If it is confirmed that some Australian acacias and Iberian Fabaceae shrubs outcompete each other outside their native range due to enemy release, the introduction of specific enemies, as recently carried out in Portugal for $A$. longifolia, can be a promising tool to control their invasions.

Besides sound comparative studies on the availability of macronutrients between Acacia spp.-invaded sites and mature stands of native Fabaceae species, another research gap is the lack of knowledge about the effects of acacias on net and gross $\mathrm{N}$ fluxes, as well as on available micronutrients, in the invaded ecosystems. Moreover, integrated studies on the effects of $\mathrm{CO}_{2}$ increase and changes in temperature, frost risk and water availability could provide a more reliable understanding of the effect of climate change on these invasive species.

In addition to reactive actions, such as eradication, the proactive restoration of areas invaded by these Acacia species must be carefully planned to recover the ecosystem composition and function without side effects. However, the complexity of controlling both invasion and restoration side effects highlights the importance of taking a preventive approach.

Data availability. No data sets were used in this article.

Author contributions. SJGP conceived the review. SJGP and CVB jointly performed the bibliographic search, analysed data and wrote the paper.

Competing interests. The authors declare that they have no conflict of interest.

Review statement. This paper was edited by Sonja Knapp and reviewed by Luke Potgieter, Ana Vaz and one anonymous referee.

\section{References}

Aedo, C., Buira, A., Medina, L., and Fernández-Albert, M.: The Iberian Vascular Flora: Richness, Endemicity and Distribution Patterns, in: The Vegetation of the Iberian Peninsula, edited by: Loidi, J., Plant and Vegetation 12, Springer, 2017.

AEMET-IMP: Iberian climate atlas. Air temperature and precipitation (1971-2000), Ministerio de Medio Ambiente y Medio Rural y Marino, Madrid, 80 pp., 2011

Aguiar, F. C., Ferreira, M. T., and Moreira, I.: Exotic and native vegetation establishment following channelization of a western Iberian river, Regul. River, 17, 509-526, https://doi.org/10.1002/rrr.642, 2001.

Aguilera, N., Becerra, J., Villaseñor-Parada, C., Lorenzo, P., González, L., and Hernández, V.: Effects and identification of chemical compounds released from the invasive Acacia dealbata Link, Chem. Ecol., 31, 479-493, 2015. 
Alpert, P., Bone, E., and Holzapfel, C.: Invasiveness, invasibility and the role of environmental stress in the spread of non-native plants, Perspect. Plant Ecol., 3, 52-66, https://doi.org/10.1078/1433-8319-00004, 2000.

Álvarez, V., Taboada Hidalgo, J. J., and Lorenzo González, M. N.: Cambio climático en Galicia en el siglo XXI: Tendencias y variabilidad en temperaturas y precipitaciones, Avances en ciencias de la tierra 2, 65-85, 2011.

ANPSA: Acacia cultriformis, available at: http://anpsa.org.au/a-cul. html (last access: 28 November 2016), 2012.

Bañares, Á., Blanca, G., Güemes, J., Moreno, J. C., and Ortiz, S: Atlas y Libro Rojo de la Flora Vascular Amenazada de España, Dirección General de Conservación de la Naturaleza, Madrid, Spain, 1069 pp., 2004.

Belay, Z., Vestberg, M., and Assefa, F.: Diversity and abundance of arbuscular mycorrhizal fungi associated with acacia trees from different land use systems in Ethiopia, Afr. J. Microbiol. Res., 7, 5503-5515, https://doi.org/10.5897/AJMR2013.61152013.

Birnbaum, C. and Leishman, M. R.: Plant-soil feedbacks do not explain invasion success of Acacia species in introduced range populations in Australia, Biol. Invasions, 15, 2609-2625, https://doi.org/10.1007/s10530-013-0478-z, 2013.

Borrelli, P., Panagos, P., Langhammer, J., Apostol, B., and Schütt, B.: Assessment of the cover changes and the soil loss potential in European forestland: First approach to derive indicators to capture the ecological impacts on soil-related forest ecosystems, Ecol. Indic., 60, 1208-1220, https://doi.org/10.1016/j.ecolind.2015.08.053, 2016.

Bossard, C. C.: Cytisus scoparius (L.) Link, in: Invasive plants of California's wildlands, edited by: Bossard, C. C., Randall, J. M., and Hoshovsky, M. C., University of California Press, Berkeley, CA, 145-150, 2000.

Brodribb, T. and Hill, R. S.: A physiological comparison of leaves and phyllodes in Acacia melanoxylon, Aust. J. Bot., 41, 293-305, https://doi.org/10.1071/bt9930293, 1993.

Brown, K. L. and Bettink, K. A.: Swan Weeds: Management Notes, FloraBase, available at: https://florabase.dpaw.wa.gov.au/weeds/ swanweeds/ (last access: 28 Novemeber 2016), 2009.

CABI: Ulex europaeus (gorse), available at: http://www.cabi.org/ isc/datasheet/55561, last access: 28 November 2016a.

CABI: Cytisus scoparius (broom), available at: http://www.cabi. org/isc/datasheet/17610, last access: 28 November 2016b.

Callaway, R. M. and Ridenour, W. M.: Novel weapons: invasive success and the evolution of increased competitive ability, Front. Ecol. Environ., 2, 436-443, https://doi.org/10.1890/15409295(2004)002[0436:NWISAT]2.0.CO;2, 2004.

Carballeira, A. and Reigosa, M. J.: Effects of natural leachates of Acacia dealbata Link in Galicia (NW Spain), Bot. Bull. Acad. Sinica, 40, 87-92, 1999.

Carrapeto Gil, A. M.: Controlo de acácias invasoras em sítios de importáncia comunitária: do planeamento aos desafios da intervenção, Master These, Escola Superior Agrária, Politécnico de Coimbra, Portugal, 2017.

Carvalho, L. M., Antunes, P. M., Martins-Loução, M. A., and Klironomos, J. N.: Disturbance influences the outcome of plantsoil biota interactions in the invasive Acacia longifolia and in native species, Oikos, 119, 1172-1180, 2010.

Casal, M.: Post-fire dynamics of shrubland dominated by Papilonaceae plants, Ecología Mediterránea 13, 87-89, 1987.
Castro-Díez, P., Godoy, O., Saldaña, A., and Richardson, D. M.: Predicting invasiveness of Australian acacias on the basis of their native climatic affinities, life history traits and human use, Divers. Distrib., 17, 934-945, 2011.

Castro-Díez, P., Fierro-Brunnenmeister, N., González-Muñoz, N., and Gallardo, A.: Effects of exotic and native tree leaf litter on soil properties of two contrasting sites in the Iberian Peninsula, Plant Soil, 350, 179-191, 2012.

Catford, J. A., Daehler, C. C., Murphy, H. T., Sheppard, A. W., Hardesty, B. D., Westcott, D. A., Rejmánek, M., Bellingham, P. J., Pergl, J., Horvitz, C. C., and Hulme, P. E.: The intermediate disturbance hypothesis and plant invasions: Implications for species richness and management, Perspect. Plant. Ecol., 14, 231-241, https://doi.org/10.1016/j.ppees.2011.12.002, 2012.

Chamier, J., Schachtschneider, K., le Maitre, D. C., Ashton, P. J., and van Wilgen, B. W.: Impacts of invasive alien plants on water quality, with particular emphasis on South Africa, Water SA (Pretoria), 38, 345-356, 2012.

Clements, D. R., Peterson, D. J., and Prasad, R.: The biology of Canadian weeds. 112. Ulex europaeus L, Can. J. Plant Sci., 81, 325-337, https://doi.org/10.4141/P99-128, 2001.

Coelho, C., Alves, F.: Plano de Ordenamento do Parque Natural do Alvão. Estudos de Caracterização - 1 Fase, available from the ICN, Parque Natural do Alvão, Universidade de Aveiro, Portugal, 61 pp., 2004.

Coetzee, B., Van Rensburg, B., and Robertson, M.: Invasion of grasslands by silver wattle, Acacia dealbata (Mimosaceae), alters beetle (Coleoptera) assemblage structure, Afr. Entomol., 15, 328-339, 2007.

Cohen, O., Gamliel, A., Katan, J., Kurzbaum, E., Riov, J., and Bar, P.: Controlling the seed bank of the invasive plant Acacia saligna: comparison of the efficacy of prescribed burning, soil solarization, and their combination, Biol. Invasions, 20, 28752887, 2018.

Corbin, J. D. and D'Antonio, C. M.: Effects of exotic species on soil nitrogen cycling: implications for restoration, Weed Technol., 18, 1464-1467, 2004.

Correia, M., Castro, S., Ferrero, V., Crisóstomo, J. A., and Rodríguez-Echeverría, S.: Reproductive biology and success of invasive Australian acacias in Portugal, Bot. J. Linn. Soc., 174, 574-588, 2014.

Correia, M., Montesinos, D., French, K., and Rodríguez-Echeverría, S.: Evidence for enemy release and increased seed production and size for two invasive Australian acacias, J. Ecol., 104, 13911399, https://doi.org/10.1111/1365-2745.12612, 2016.

Cory, J. S. and Myers, J. H.: Direct and indirect ecological effects of biological control, Trends Ecol. Evol., 15, 137-139, https://doi.org/10.1016/S0169-5347(99)01807-8, 2000.

Daehler, C. C.: Performance comparisons of co-occurring native and alien invasive plants: Implications for conservation and restoration, Annu. Rev. Ecol. Evol. S., 34, 183-211, 2003.

DAISIE Project: available at: http://www.europe-aliens.org/, last access: 18 November 2016.

D'Antonio, C. and Meyerson, L. A.: Exotic plant species as problems and solutions in ecological restoration: A synthesis, Restor. Ecol., 10, 703-713, 2002.

Dassonville, N., Vanderhoeven, S., Vanparys, V., Hayez, M., Gruber, W., and Meerts, P.: Impacts of alien invasive plants on soil 
nutrients are correlated with initial site conditions in NW Europe, Oecologia, 157, 131-140, 2008.

Davidson, A. M., Jennions, M., and Nicotra, A. B.: Do invasive species show higher phenotypic plasticity than native species and, if so, is it adaptive? A meta-analysis, Ecol. Lett., 14, 419431, 2011.

De Wit, M. P., Crookes, D. J., and van Wilgen, B. W.: Conflicts of interest in environmental management: estimating the costs and benefits of a tree invasion, Biol. Invasiosn, 3, 167-178, 2001.

Downey, P. O.: Disturbance and invasion ecology of Scotch broom (Cytisus scoparius (L.) Link) in Australia, PhD These, University of New England, Armidale, Australia, 2001.

Duponnois, R., Baudoin, E., Sanguin, H., Thioulouse, J., Le Roux, C., Tournier, E., Galiana, A., Prin, Y., and Dreyfus, B.: L'introduction d'acacias australiens pour réhabiliter des écosystèmes dégradés est-elle dépourvue de risques environnementaux?, Bois et forêts des tropiques, 318, 59-65, 2013.

EFSA PLH Panel: Risk to plant health in the EU territory of the intentional release of the bud-galling wasp Trichilogaster acaciaelongifoliae for the control of the invasive alien plant Acacia longifolia, EFSA Journal, 13, 4079, https://doi.org/10.2903/j.efsa.2015.4079, 2015.

Ehrenfeld, J. G.: Ecosystem consequences of biological invasions, Annu. Rev. Ecol. Evol. S., 41, 59-80, 2010.

Ehrenfeld, J. G., Kourtev, P., and Huang, W.: Changes in soil functions following invasions of exotic understory plants in deciduous forests, Ecol. Appl., 11, 1287-1300, https://doi.org/10.1890/10510761(2001)011[1287:CISFFI]2.0.CO;2, 2001.

Enright, W.: The effect of terrestrial invasive alien plants on water scarcity in South Africa, Phys. Chem. Earth Pt. B, 25, 237-242, 2000.

European Commission: Soil $\mathrm{pH}$ in Europe, available at: https://esdac.jrc.ec.europa.eu/themes/soil-ph\#tabs-0-resources_ by_type $=0$ (last access: 24 May 2019), 2010.

European Parliament and Council: Prevention and management of the introduction and spread of invasive alien species, Regulation (EU) No 1143/2014, Official Journal of the European Union, 57, 35-55, 2014.

Fagúndez, J. and Beiras, M. B.: Plantas invasoras de Galicia: bioloxía, distribución e métodos de control, Dirección Xeral de Conservación da Natureza, Santiago de Compostela, 209 pp., 2007.

Fernandes, M. M.: Acácias e geografia histórica: rotas de um percurso global (parte1), Cadernos Curso de Doutoramento em Geografia, 4, 23-40, 2012.

Fernandes, M. M., Devy-Vareta, N., and Rangan, H.: Plantas exóticas invasoras e instrumentos de gestão territorial. $\mathrm{O}$ caso paradigmático do género Acacia em Portugal, Revista de Geografia e Ordenamento do Território, 4, 83-107, 2013.

Fernandes, P., Antunes, C., Correia, O., and Maguas, C.: Do climatic and habitat conditions affect the reproductive success of an invasive tree species? An assessment of the phenology of Acacia longifolia in Portugal, Plant Ecol., 216, 343-355, https://doi.org/10.1007/s11258-014-0441-9, 2015.

Fernandes-Fontes, A. M. P. and Bento-Gonçalves, A. J.: Cartografia de risco de incêndio no parque nacional da Peneda-Gerês e gestão adequada dos recursos florestais e sistemas naturais, $\mathrm{X}$ Colóquio Ibérico de Geografia, Évora, 22-24 September, 2005.
Fernández-Bouzas, J. A., Bonache-López, J., and Gordillo, E.: Parque Nacional das Illas Atlánticas de Galicia, Recursos Rurais, 2, 91-102, 2005.

Fogarty, G. and Facelli, J. M.: Growth and competition of Cytisus scoparius, an invasive shrub, and Australian native shrubs, Plant Ecol., 144, 27-35, https://doi.org/10.1023/a:1009808116068, 1999.

Forrester, D. I., Vanclay, J. K., and Forrester, R. I.: The balance between facilitation and competition in mixtures of Eucalyptus and Acacia changes as stands develop, Oecologia, 166, 265-272, 2011.

Fuentes-Ramírez, A., Pauchard, A., Marticorena, A., and Sánchez, P.: Relationship between the invasion of Acacia dealbata Link (Fabaceae: Mimosoideae) and plant species richness in SouthCentral Chile, Gayana Bot., 67, 188-197, 2010.

Fuentes-Ramírez, A., Pauchard, A., Cavieres, L. A., and García, R. A.: Survival and growth of Acacia dealbata vs. native trees across an invasion front in south-central Chile, Forest Ecol. Manag., 261, 1003-1009, 2011.

Funk, J. L. and Vitousek, P. M.: Resource-use efficiency and plant invasion in low-resource systems, Nature, 446, 1079-1081, 2007.

Funk, J. L., Cleland, E. E., Suding, K. N., and Zavaleta, E. S.: Restoration through reassembly: plant traits and invasion resistance, Trends Ecol. Evol., 23, 695-703, https://doi.org/10.1016/j.tree.2008.07.013, 2008.

GEIB: TOP 20: Las 20 especies exóticas invasoras más dañinas presentes en España, Serie Técnica N.2, GEIB, 116 pp., 2006.

Gibson, M. R., Richardson, D. M., Marchante, E., Marchante, H., Rodger, J. G., Stone, G. N., Byrne, M., Fuentes-Ramírez, A., George, N., and Harris, C.: Reproductive biology of Australian acacias: important mediator of invasiveness?, Divers. Distrib., 17, 911-933, 2011.

Giovanetti, M., Vuković, N., and Jelaska, S.: Australian acacias across eastern Adriatic - abundant but not aggressive, Period. Biol., 116, 275-283, 2014.

Giovanetti, M., Ramos, M., and Máguas, C.: Why so many flowers? A preliminary assessment of mixed pollination strategy enhancing sexual reproduction of the invasive Acacia longifolia in Portugal, Web Ecol., 18, 47-54, https://doi.org/10.5194/we-1847-2018, 2018.

Global Invasive Species Database: available at: http://issg.org/ database/welcome/, last access: 28 November 2016.

Gonçalves-Aguiar, C. F.: Flora e vegetação da Serra de Nogueira e do Parque Natural de Montesinho, Engenharia agronómica, Instituto Superior de Agronomia, Universidade Técnica de Lisboa, Lisboa, 659 pp., 2000.

González-Muñoz, N., Costa-Tenorio, M., and Espigares, T.: Invasion of alien Acacia dealbata on Spanish Quercus robur forests: Impact on soils and vegetation, Forest Ecol. Manag., 269, 214 221, 2012.

González-Muñoz, N., Linares, J. C., Castro-Díez, P., and SassKlaassen, U.: Predicting climate change impacts on native and invasive tree species using radial growth and twenty-first century climate scenarios, Eur. J. Forest Res., 133, 1073-1086, 2014.

Griffin, A., Midgley, S., Bush, D., Cunningham, P., and Rinaudo, A.: Global uses of Australian acacias-recent trends and future prospects, Divers. Distrib., 17, 837-847, 2011. 
Haubensak, K. A., D’Antonio, C. M., and Alexander, J.: Effects of nitrogen-fixing shrubs in Washington and coastal California, Weed Technol., 18, 1475-1479, https://doi.org/10.1614/0890037X(2004)018[1475:EONSIW]2.0.CO;2, 2004.

Heleno, R. H., Ross, G., Everard, A. M. Y., Memmott, J., and Ramos, J. A.: The role of avian "seed predators" as seed dispersers, Ibis, 153, 199-203, https://doi.org/10.1111/j.1474919X.2010.01088.x, 2011.

Hellmann, C., Sutter, R., Rascher, K. G., Máguas, C., Correia, O., and Werner, C.: Impact of an exotic $\mathrm{N}_{2}$-fixing Acacia on composition and $\mathrm{N}$ status of a native Mediterranean community, Acta Oecol., 37, 43-50, 2011.

Hernández, L., Martínez-Fernández, J., Cañellas, I., and de la Cueva, A. V.: Assessing spatio-temporal rates, patterns and determinants of biological invasions in forest ecosystems. The case of Acacia species in NW Spain, Forest Ecol. Manag., 329, 206213, 2014.

Heywood, V. H. and Ball, P. W.: Leguminosae, in: Flora Europaea, edited by: Tutin, T. G., Heywood, V. H., Burges, N. A., Moore, D. M., Valentine, D. H., Walters, S. M., and Webb, D. A., Cambridge University Press, Cambridge, UK, 80-191, 1968.

Hierro, J. L., Maron, J. L., and Callaway, R. M.: A biogeographical approach to plant invasions: the importance of studying exotics in their introduced and native range, J. Ecol., 93, 5-15, https://doi.org/10.1111/j.0022-0477.2004.00953.x, 2005.

Hill, R. L., Gourlay, A. H., and Barker, R. J.: Survival of Ulex europaeus seeds in the soil at three sites in New Zealand, New Zeal. J. Bot., 39, 235-244, https://doi.org/10.1080/0028825X.2001.9512734, 2001.

Hodkinson, D. J. and Thompson, K.: Plant dispersal: the role of man, J. Appl. Ecol., 34, 1484-1496, 1997.

Hoffmann, J., Impson, F., Moran, V., and Donnelly, D.: Biological control of invasive golden wattle trees (Acacia pycnantha) by a gall wasp, Trichilogaster sp. (Hymenoptera: Pteromalidae), in South Africa, Biol. Control, 25, 64-73, 2002.

Hornoy, B., Tarayre, M., Hervé, M., Gigord, L., and Atlan, A.: Invasive Plants and Enemy Release: Evolution of Trait Means and Trait Correlations in Ulex europaeus, PLoS ONE, 6, e26275, https://doi.org/10.1371/journal.pone.0026275, 2011.

Hussain, M. I., González, L., and Reigosa, M. J.: Allelopathic potential of Acacia melanoxylon on the germination and root growth of native species, Weed Biol. Manag., 11, 18-28, 2011.

ICNB: Espécies Exóticas em Portugal. Ponto de situação (20072010), Instituto da Conservação da Natureza e da Biodiversidade, 2011.

ICNF: Parques Naturais, available at: http://www.icnf.pt/portal/ap/ p-nat, last access: 28 November 2016.

Invasive Plants in Portugal: What are they, where are they and how to control them, available at: http://invasoras.pt/en/, last access: 24 November 2019.

ISSG: Global Invasive Species Database, available at: http://www. iucngisd.org/gisd/, last access: 9 November 2016.

Ivens, G. W.: Seasonal germination and establishment of gorse, Proceedings of the NZ Weed and Pest Control Conference, 35, 152156, 1982.

Kaal, J., Carrión Marco, Y., Asouti, E., Martín Seijo, M., Martínez Cortizas, A., Costa Casais, M., and Criado Boado, F.: Long-term deforestation in NW Spain: linking the Holocene fire history to vegetation change and human activities, Quaternary Sci. Rev.,
30, 161-175, https://doi.org/10.1016/j.quascirev.2010.10.006, 2011.

Keane, R. M. and Crawley, M. J.: Exotic plant invasions and the enemy release hypothesis, Trends Ecol. Evol., 17, 164-170, https://doi.org/10.1016/S0169-5347(02)02499-0, 2002.

Keeley, J. E., Baer-Keeley, M., and Fotheringham, C. J.: Alien plant dynamics following fire in Mediterraneanclimate California shrublands, Ecol. Appl., 15, 2109-2125, https://doi.org/10.1890/04-1222, 2005.

Kull, C. A., Shackleton, C. M., Cunningham, P. J., Ducatillon, C., Dufour-Dror, J.-M., Esler, K. J., Friday, J. B., Gouveia, A. C., Griffin, A. R., Marchante, E., Midgley, S. J., Pauchard, A., Rangan, H., Richardson, D. M., Rinaudo, T., Tassin, J., Urgenson, L. S., von Maltitz, G. P., Zenni, R. D., and Zylstra, M. J.: Adoption, use and perception of Australian acacias around the world, Divers. Distrib., 17, 822-836, https://doi.org/10.1111/j.14724642.2011.00783.x, 2011.

Lazzaro, L., Giuliani, C., Fabiani, A., Agnelli, A. E., Pastorelli, R., Lagomarsino, A., Benesperi, R., Calamassi, R., and Foggi, B.: Soil and plant changing after invasion: The case of Acacia dealbata in a Mediterranean ecosystem, Sci. Total Environ., 497, 491-498, 2014.

Leary, J. K., Hue, N. V., Singleton, P. W., and Borthakur, D.: The major features of an infestation by the invasive weed legume gorse (Ulex europaeus) on volcanic soils in Hawaii, Biol. Fertil. Soils, 42, 215-223, https://doi.org/10.1007/s00374-005-0018-9, 2006.

Le Maitre, D. C., van Wilgen, B. W., Gelderblom, C. M., Bailey, C., Chapman, R. A., and Nel, J. A.: Invasive alien trees and water resources in South Africa: case studies of the costs and benefits of management, Forest Ecol. Manag., 160, 143-159, 2002.

Le Maitre, D. C., Gaertner, M., Marchante, E., Ens, E. J., Holmes, P. M., Pauchard, A., O’Farrell, P. J., Rogers, A. M., Blanchard, R., Blignaut, J., and Richardson, D. M.: Impacts of invasive Australian acacias: implications for management and restoration, Divers. Distrib., 17, 1015-1029, 2011.

Loidi, J.: Introduction to the Iberian Peninsula, General Features: Geography, Geology, Name, Brief History, Land Use and Conservation, in: The Vegetation of the Iberian Peninsula, edited by: Loidi, J., Plant and Vegetation 12, 1, Springer, 2017.

Lorenzo, P. and Rodríguez-Echeverría, S.: Influence of soil microorganisms, allelopathy and soil origin on the establishment of the invasive Acacia dealbata, Plant Ecol. Divers., 5, 67-73, 2012.

Lorenzo, P., Gonzalez, L., and Reigosa, M. J.: The genus Acacia as invader: the characteristic case of Acacia dealbata Link in $\mathrm{Eu}-$ rope, Ann. For. Sci., 67, https://doi.org/10.1051/forest/2009082, 2010a.

Lorenzo, P., Rodríguez-Echeverría, S., González, L., and Freitas, H.: Effect of invasive Acacia dealbata Link on soil microorganisms as determined by PCR-DGGE, Appl. Soil Ecol., 44, 245251, 2010b.

Lorenzo, P., Palomera-Pérez, A., Reigosa, M. J., and González, L.: Allelopathic interference of invasive Acacia dealbata Link on the physiological parameters of native understory species, Plant Ecol., 212, 403-412, 2011.

Lorenzo, P., Pazos-Malvido, E., Rubido-Bará, M., Reigosa, M. J., and González, L.: Invasion by the leguminous tree Acacia dealbata (Mimosaceae) reduces the native understorey plant species in different communities, Aust. J. Bot., 60, 669-675, 2012. 
Lorenzo, P., Pereira, C. S., and Rodríguez-Echeverría, S.: Differential impact on soil microbes of allelopathic compounds released by the invasive Acacia dealbata Link, Soil Biol. Biochem., 57, 156-163, 2013.

Lorenzo-Fernández, M., Arcos-Fernández, F., and Planelles de Miguel, P.: Plan de Ordenación dos Recursos Naturais. Parque Natural do Monte Aloia, Dirección Xeral de Conservación da Natureza, Pontevedra, Spain, 2000.

Low, T.: Australian acacias: weeds or useful trees?, Biol. Invasions, 14, 2217-2227, 2012.

MAGRAMA: Catálogo Español de Especies Exóticas Invasoras, available at: http://www.magrama.gob.es/ (last access: 28 November 2016), 2013.

MAPAMA: Acacia salicina Lindl, available at: http://www.mapama.gob.es/es/biodiversidad/temas/ conservacion-de-especies/acacia_salicina_2013_tcm7-306912. pdf (last access: 28 November 2016), 2013.

Marchante, E., Kjøller, A., Struwe, S., and Freitas, H.: Short-and long-term impacts of Acacia longifolia invasion on the belowground processes of a Mediterranean coastal dune ecosystem, Appl. Soil Ecol., 40, 210-217, 2008.

Marchante, E., Kjøller, A., Struwe, S., and Freitas, H.: Soil recovery after removal of the $\mathrm{N}_{2}$-fixing invasive Acacia longifolia: consequences for ecosystem restoration, Biol. Invasions, 11, 813-823, 2009.

Marchante, H., Marchante, E., and Freitas, H.: Invasion of the Portuguese dune ecosystems by the exotic species Acacia longifolia (Andrews) Willd.: effects at the community level, in: Plant Invasions: Ecological Threats and Management Solutions, edited by: Child, L. E., Brock, J. H., Brundu, G., Prach, K., Pysek, P., Wade, P. M., and Williamson, M., Backhuys, Leiden, The Netherlands, 75-85, 2003.

Marchante, H., Marchante, E., and Freitas, H.: Invasive plant species in Portugal: an overview, International workshop on invasive plants in Mediterranean type regions of the world, 25-27 May 2005, Environmental Encounters Series, 2005.

Marchante, H., Freitas, H., and Hoffmann, J. H.: Seed ecology of an invasive alien species, Acacia longifolia (Fabaceae), in Portuguese dune ecosystems, Am. J. Bot., 97, 1780-1790, 2010.

Marchante, H., Freitas, H., and Hoffmann, J. H.: Post-clearing recovery of coastal dunes invaded by Acacia longifolia: is duration of invasion relevant for management success?, J. Appl. Ecol., 48, 1295-1304, 2011a.

Marchante, H., Freitas, H., and Hoffmann, J. H.: Assessing the suitability and safety of a well-known bud-galling wasp, Trichilogaster acaciaelongifoliae, for biological control of Acacia longifolia in Portugal, Biol. Control, 56, 193-201, https://doi.org/10.1016/j.biocontrol.2010.11.001, 2011b.

Marchante, H., Morais, M., Freitas, H., and Marchante, E.: Guia prático para a identificação de plantas invasoras em Portugal, edited by: Marchante, H., Morais, M., Freitas, H., and Marchante, E., Imprensa da Universidade de Coimbra, Coimbra, 208 pp., 2014.

Marchante, H., Marchante, E., Freitas, H., and Hoffmann, J. H.: Temporal changes in the impacts on plant communities of an invasive alien tree, Acacia longifolia, Plant Ecol., 216, 1481-1498, 2015.

Marchante, H. S., Marchante, E. M., Buscardo, E., Maia, J., and Freitas, H.: Recovery potential of dune ecosystems invaded by an exotic Acacia species (Acacia longifolia), Weed Technol., 18, 1427-1433, https://doi.org/10.1614/0890037x(2004)018[1427:rpodei]2.0.co;2, 2004.

Martins, F., Alegria, C., and Gil, A.: Mapping invasive alien Acacia dealbata Link using ASTER multiespectral imagery: a case study in central-eastern of Portugal, Forest Syst, 25, 1-15, 2016.

Maryland Department of Agriculture: Weed Risk Assessment for Cytisus scoparius (L.) Link (Fabaceae) - Scotch broom, available at: http://mda.maryland.gov/plants-pests/Documents/ CytisusScoparius_WRA_120115.pdf (last access: 28 November 2016), 2015.

Maslin, B. R.: Introduction to Acacia, in: Flora of Australia, edited by: Orchard, A. E. and Wilson, A. J. G., ABRS/CSIRO, Melbourne, Australia, 3-13, 2001.

May, B. M. and Attiwill, P. M.: Nitrogen-fixation by Acacia dealbata and changes in soil properties 5 years after mechanical disturbance or slash-burning following timber harvest, Forest Ecol. Manag., 181, 339-355, https://doi.org/10.1016/S03781127(03)00006-9, 2003.

Memmott, J., Fowler, S. V., Paynter, Q., Sheppard, A. W., and Syrett, P.: The invertebrate fauna on broom, Cytisus scoparius, in two native and two exotic habitats, Acta Oecol., 21, 213-222, https://doi.org/10.1016/S1146-609X(00)00124-7, 2000.

Miller, J. T., Murphy, D. J., Brown, G. K., Richardson, D. M., and González-Orozco, C. E.: The evolution and phylogenetic placement of invasive Australian Acacia species, Divers. Distrib., 17, 848-860, 2011.

Ministério do Ambiente: Decreto-Lei no. 565/99, de 21 dezembro, Diário da República - I Série - A, 295, 9100-9114, 1999.

Mokotjomela, T. M., Hoffmann, J. H., and Downs, C. T.: The potential for birds to disperse the seeds of Acacia cyclops, an invasive alien plant in South Africa, Ibis, 157, 449-458, 2015.

Monaco, A. and Genovesi, P.: European Guidelines on Protected Areas and Invasive Alien Species, Council of Europe, Strasbourg, Regional Parks Agency, Lazio Region, Rome, Italy, 60 pp., 2014.

Moore, J. H., Sandiford, E., Austin, E., and Poulish, G.: Controlling gorse seed banks, Proceedings of the 15th Australian Weeds Conference, Adelaide, 2006, 283-286, 2006.

Morais, M. C. and Freitas, H.: Phenological dynamics of the invasive plant Acacia longifolia in Portugal, Weed Res., 55, 555-564, 2015.

Morris, T. L., Esler, K. J., Barger, N. N., Jacobs, S. M., and Cramer, M. D.: Ecophysiological traits associated with the competitive ability of invasive Australian acacias, Divers. Distrib., 17, 898910, 2011.

Moss, G. R.: The gorse seed problem, Proceedings of the 12th New Zealand Plant Protection Conference 1959, 12, 59-64, 1959.

Muséum National d'Histoire Naturelle: Inventaire National du Patrimoine Naturelm available at: https://inpn.mnhn.fr, last access: 28 November 2016.

Myers, J. H., Simberloff, D., Kuris, A. M., and Carey, J. R.: Eradication revisited: dealing with exotic species, Trends Ecol. Evol., 15, 316-320, 2000.

Nemoto, M., Nakagoshi, N., Horie, H., and Nishimura, N.: Allelopathic potential of broom (Sarothamnus scoparius) dominating post-fire stands in southwest Japan, Proceedings of the 10th Australian and 14th Asian-Pacific Weed Conference Brisbane, 1993, 333-338, 1993. 
Neto, C. S.: A flora e a vegetação das dunas de S. Jacinto, Finisterra, 28, 101-148, 1993.

Nsikani, M. M., Gaertner, M., Kritzinger-Klopper, S., Ngubane, N. P., and Esler, K. J.: Secondary invasion after clearing invasive Acacia saligna in the South African fynbos, S. African J. Bot., 125, 280-289, 2019.

Panetta, F. D.: Weed eradication-an economic perspective, Invas. Plant Sci. Mana., 2, 360-368, 2009.

Parepa, M., Fischer, M., and Bossdorf, O.: Environmental variability promotes plant invasion, Nat. Commun., 4, 1604, https://doi.org/10.1038/ncomms2632, 2013.

Parker, I. M.: Invasion dynamics of Cytisus scoparius: a matrix model approach, Ecol. Appl., 10, 726-743, https://doi.org/10.1890/10510761(2000)010[0726:IDOCSA]2.0.CO;2, 2000.

Parker, M. A.: Mutualism as a constraint on invasion success for legumes and rhizobia, Divers. Distrib., 7, 125-136, 2001.

Pascov, C. M., Nevill, P. G., Elliott, C. P., Majer, J. D., Anthony, J. M., and Krauss, S. L.: The critical role of ants in the extensive dispersal of Acacia seeds revealed by genetic parentage assignment, Oecologia (Berlin), 179, 1123-1134, 2015.

Perry, G. L. W., Wilmshurst, J. M., and McGlone, M. S.: Ecology and long-term history of fire in New Zealand, New Zeal. J. Ecol., 38, 157-176, 2014.

Pohlman, C. L., Nicotra, A. B., and Murray, B. R.: Geographic range size, seedling ecophysiology and phenotypic plasticity in Australian Acacia species, J. Biogeogr., 32, 341-351, 2005.

Power, S. C., Cramer, M. D., Verboom, G. A., and Chimphango, S. B.: Does phosphate acquisition constrain legume persistence in the fynbos of the Cape Floristic Region?, Plant Soil, 334, 33-46, 2010.

Puentes, M. A., Pereiras, J., and Casal, M.: Study of the seedbank of Ulex europaeus L. shrublands in Galicia (NW Spain) 1. First results, Revue d'Ecologie et du Sol, 25, 215-224, 1988.

Pulgar-Sañudo, I., Amigo-Vázquez, J., and Giménez-de-Azcárate, J.: Guía da flora do Parque Natural Fragas do Eume, Dirección Xeral de Conservación da Natureza, Xunta de Galicia, 108 pp., 2006.

Rascher, K. G., Große-Stoltenberg, A., Máguas, C., and Werner, C.: Understory Invasion by Acacia longifolia Alters the Water Balance and Carbon Gain of a Mediterranean Pine Forest, Ecosystems, 14, 904-919, https://doi.org/10.1007/s10021-011-9453-7, 2011.

Rascher, K. G., Hellmann, C., Máguas, C., and Werner, C.: Community scale ${ }^{15} \mathrm{~N}$ isoscapes: tracing the spatial impact of an exotic $\mathrm{N}_{2}$-fixing invader, Ecol. Lett., 15, 484-491, 2012.

Rees, M. and Paynter, Q.: Biological control of Scotch broom: modelling the determinants of abundance and the potential impact of introduced insect herbivores, J. Appl. Ecol., 34, 1203-1221, 1997.

Richardson, D. M., Pyšek, P., Rejmánek, M., Barbour, M. G., Panetta, F. D., and West, C. J.: Naturalization and invasion of alien plants: concepts and definitions, Divers. Distrib., 6, 93-107, 2000.

Richardson, D. M., Holmes, P. M., Esler, K. J., Galatowitsch, S. M., Stromberg, J. C., Kirkman, S. P., Pyšek, P., and Hobbs, R. J.: Riparian vegetation: degradation, alien plant invasions, and restoration prospects, Divers. Distrib., 13, 126-139, 2007.
Richardson, D. M. and Rejmánek, M.: Trees and shrubs as invasive alien species - a global review, Divers. Distrib., 17, 788-809, 2011.

Richardson, D. M. and Kluge, R. L.: Seed banks of invasive Australian Acacia species in South Africa, Perpect. Plant Ecol., 10, 161-177, 2008.

Richardson, D. M., Carruthers, J., Hui, C., Impson, F. A., Miller, J. T., Robertson, M. P., Rouget, M., Le Roux, J. J., and Wilson, J. R.: Human-mediated introductions of Australian acaciasa global experiment in biogeography, Divers. Distrib., 17, 771787, 2011.

Richardson, D. M., Le Roux, J. J., and Wilson, J. R. U.: Australian acacias as invasive species: lessons to be learnt from regions with long planting histories, South. Forests, 77, 31-39, 2015.

Richardson, R. G. and Hill, R. L.: The biology of Australian weeds. 34. Ulex europaeus L, Plant Protection Quarterly, 13, 46-58, 1998.

Rivas-Martínez, S., Penas, A., del Río, S., Díaz González, T. E., and Rivas-Sáenz, S.: Bioclimatology of the Iberian Peninsula and the Balearic Islands, in: The Vegetation of the Iberian Peninsula, edited by: Loidi, J., Plant and Vegetation 12, Springer, 2017.

Rodríguez-Echeverría, S., Pérez-Fernández, M. A., Vlaar, S., and Finnan, T.: Analysis of the legume-rhizobia symbiosis in shrubs from central western Spain, J. Appl. Microbiol., 95, 1367-1374, https://doi.org/10.1046/j.1365-2672.2003.02118.x, 2003.

Rodríguez-Echeverría, S., Crisóstomo, J., Nabais, C., and Freitas, H.: Belowground mutualists and the invasive ability of Acacia longifolia in coastal dunes of Portugal, Biol. Invasions, 11, 651661, https://doi.org/10.1007/s10530-008-9280-8, 2009.

Rodríguez-Echeverría, S.: Rhizobial hitchhikers from Down Under: invasional meltdown in a plant-bacteria mutualism?, J. Biogeogr., 37, 1611-1622, 2010.

Rodríguez-Echeverría, S., Le Roux, J. J., Crisóstomo, J. A., and Ndlovu, J.: Jack-of-all-trades and master of many? How does associated rhizobial diversity influence the colonization success of Australian Acacia species? Divers. Distrib., 17, 946-957, 2011.

Rodríguez-Echeverría, S., Afonso, C., Correia, M., Lorenzo, P., and Roiloa, S. R.: The effect of soil legacy on competition and invasion by Acacia dealbata Link, Plant Ecol., 214, 1139-1146, 2013.

Saad, L., Jacquemart, A.-L., Cawoy, V., Vanparys, V., Vervoort, A., Meerts, P., Dassonville, N., Domken, S., and Mahy, G.: Les plantes exotiques envahissantes en Belgique ont-elles des impacts?, Parcs \& Réserves, Namur, Belgium, Ardenne et Gaume, 64, 10-16, 2009.

Sanz-Elorza, M., Vesperinas, E. S., and Sánchez, E. D. D. (Eds): Atlas de las plantas alóctonas invasoras en España. Dirección General para la Biodiversidad, Ministerio de Medio Ambiente, Madrid, 2004.

Schortemeyer, M., Atkin, O., McFarlane, N., and Evans, J.: $\mathrm{N}_{2}$ fixation by Acacia species increases under elevated atmospheric $\mathrm{CO}_{2}$, Plant, Cell Environ., 25, 567-579, 2002.

Sheppard, A., Shaw, R., and Sforza, R.: Top 20 environmental weeds for classical biological control in Europe: a review of opportunities, regulations and other barriers to adoption, Weed Res., 46, 93-117, 2006.

Silva, J. S. and Marchante, H.: Post-fire management of exotic forests, in: Post-fire management and restoration of Southern European forests, edited by: Moreira, F., Arianoutsou, M., Corona, 
P., and De las Heras, J., Managing Forest Ecosystems, 24, Springer Dordrecht, 223-255, 2012.

Slabbert, E., Jacobs, S. M., and Jacobs, K.: The soil bacterial communities of South African fynbos riparian ecosystems invaded by Australian Acacia species, PloS ONE, 9, e86560, https://doi.org/10.1371/journal.pone.0086560, 2014.

Sokal, R. R. and Rohlf, F. J.: Biometría: principios y métodos estadísticos en la investigación biológica, Madrid, H. Blume Ediciones, 832 pp., 1979.

Souza-Alonso, P., Lorenzo, P., Rubido-Bará, M., and González, L.: Effectiveness of management strategies in Acacia dealbata Link invasion, native vegetation and soil microbial community responses, Forest Ecol. Manag., 304, 464-472, 2013.

Souza-Alonso, P., Novoa, A., and González, L.: Soil biochemical alterations and microbial community responses under Acacia dealbata Link invasion, Soil Biol. Biochem., 79, 100-108, 2014.

Souza-Alonso, P., Guisande-Collazo, A., and González, L.: Gradualism in Acacia dealbata Link invasion: Impact on soil chemistry and microbial community over a chronological sequence, Soil Biol. Biochem., 80, 315-323, 2015a.

Souza-Alonso, P., Guisande, A., and Gonzalez, L.: Structural changes in soil communities after triclopyr application in soils invaded by Acacia dealbata Link, J. Environ. Sci. Heal. B, 50, 184-189, https://doi.org/10.1080/03601234.2015.982419, 2015 b.

Souza-Alonso, P., Rodríguez, J., González, L., and Lorenzo, P.: Here to stay. Recent advances and perspectives about Acacia invasión in Mediterranean areas, Ann. For. Sci., 74, 1-20, 2017.

Strayer, D. L., Eviner, V. T., Jeschke, J. M., and Pace, M. L.: Understanding the long-term effects of species invasions, Trends Ecol. Evol., 21, 645-0651, 2006.

TRAGSA: Actuaciones de control de especies alóctonas invasoras en el entorno del Parque Nacional de Picos de Europa 2009, Ministerio de Medio Ambiente y Medio Rural y Marino, 75 pp., 2009.

Van Wilgen, B. W. and Richardson, D. M.: The effects of alien shrub invasions on vegetation structure and fire behaviour in South African fynbos shrublands: a simulation study, J. Appl. Ecol., 22, 955-966, 1985.

Van Wilgen, B. W., Dyer, C., Hoffman, J. H., Ivey, P., Le Maitre, D. C., Moore, J. L., Richardson, D. M., Rouget, M., Wannenburgh, A., and Wilson, R. U.: National-scale strategic approaches for managing introduced plants: insights from Australian acacias in South Africa, Divers. Distrib., 17, 1060-1075, 2011.

Vaz, A. S., Ribeiro, J., Honrado, J. P., and Vicente, J. R.: Stakeholders' perceptions towards non-native acacias and implications for their management in Portugal, Forestry, 1-10, https://doi.org/0.1093/forestry/cpz060, 2019.

Vazquez-de-la-Cueva, A.: Case studies of the expansion of Acacia dealbata in the valley of the river Miño (Galicia, Spain), For. Syst., 23, 3-14, https://doi.org/10.5424/fs/2014231-02531, 2014.

Viana, H. and Aranha, J.: Estudo da alteração da cobertura do solo no Parque Nacional da Peneda Gerês (1995 e 2007). Análise temporal dos padrões espaciais e avaliação quantitativa da estrutura da paisagem, X Encontro de Utilizadores de Informação Geográfica, Oeiras, 14-16 May 2008.
Vicente, J., Fernandes, R., Randin, C., Broennimann, O., Gonçalves, J., Marcos, B., Pôças, I., Alves, P., Guisan, A., and Honrado, J.: Will climate change drive alien invasive plants into areas of high protection value? An improved model-based regional assessment to prioritise the management of invasions, J. Environ. Manag., 131, 185-195, 2013.

Vicente, J. R., Kueffer, C., Richardson, D. M., Vaz, A. S., Cabral, J. A., Hui, C., Araújo, M. B., Kühn, I., Kull, C. A., Verburg, P. H., Marchante, E., and Honrado, J. P.: Different environmental drivers of alien tree invasion affect different life-stages and operate at different spatial scales, For. Ecol. Manag., 433, 263-275, 2019.

Wandrag, E. M., Sheppard, A., Duncan, R. P., and Hulme, P. E.: Reduced availability of rhizobia limits the performance but not in vasiveness of introduced Acacia, J. Ecol., 101, 1103-1113, 2013.

Weidenhamer, J. D. and Callaway, R. M.: Direct and indirect effects of invasive plants on soil chemistry and ecosystem function, J. Chem. Ecol., 36, 59-69, 2010.

Werner, C., Zumkier, U., Beyschlag, W., and Máguas, C.: High competitiveness of a resource demanding invasive acacia under low resource supply, Plant Eco.1, 206, 83-96, 2010.

Williams, R. J. P. and Fraústo da Silva, J. J. R.: The distribution of elements in cells, Coordin. Chem. Rev., 200-202, 247-348, 2000.

Wilson, J. R. U., Gairifo, C., Gibson, M. R., Arianoutsou, M., Bakar, B. B., Baret, S., Celesti-Grapow, L., DiTomaso, J. M., Dufour-Dror, J.-M., Kueffer, C., Kull, C. A., Hoffmann, J. H., Impson, F. A. C., Loope, L. L., Marchante, E., Marchante, H., Moore, J. L., Murphy, D. J., Tassin, J., Witt, A., Zenni, R. D., and Richardson, D. M.: Risk assessment, eradication, and biological control: global efforts to limit Australian acacia invasions, Divers. Distrib., 17, 1030-1046, https://doi.org/10.1111/j.14724642.2011.00815.x, 2011.

Witkowski, E.: Effects of invasive alien acacias on nutrient cycling in the coastal lowlands of the Cape fynbos, J. Appl. Ecol., 28, $1-15,1991$.

WorldWideWattle: Species Gallery, available at: http: //worldwidewattle.com/speciesgallery/home.php, last access: 28 November 2016.

Xunta de Galicia: Plan Reitor de Uso e Xestión do Parque Natural das Fragas do Eume, Documento Preliminar, Dirección Xeral de Conservación da Natureza. Xunta de Galicia, Spain, 158 pp., 2014.

Yelenik, S. G., Stock, W. D., and Richardson, D. M.: Ecosystem level impacts of invasive Acacia saligna in the South African fynbos, Restor. Ecol., 12, 44-51, 2004.

Yelenik, S. G., Stock, W. D., and Richardson, D. M.: Functional group identity does not predict invader impacts: differential effects of nitrogen-fixing exotic plants on ecosystem function, Biol. Invasions, 9, 117-125, 2007.

Yessoufou, K., Mearns, K., Elansary, H. O., and Hendrik Stoffberg, G.: Assessing the phylogenetic dimension of Australian Acacia species introduced outside their native ranges, Bot. Lett., 163, 33-39, https://doi.org/10.1080/12538078.2015.1124288, 2016. 